\title{
Lipoprotein Drug Delivery Vehicles for Cancer: Rationale and Reason
}

\author{
Jaideep Chaudhary $1,+\left(\mathbb{D}\right.$, Joseph Bower ${ }^{1,+}$ and Ian R. Corbin $1,2,3, *$ \\ 1 Advanced Imaging Research Center, University of Texas Southwestern Medical Center at Dallas, Dallas, \\ TX 75390, USA; jaideep.chaudhary@utsouthwestern.edu (J.C.); joseph.bower@utsouthwestern.edu (J.B.) \\ 2 Department of Radiology, University of Texas Southwestern Medical Center at Dallas, Dallas, TX 75390, USA \\ 3 Internal Medicine Division of Liver and Digestive Diseases, University of Texas Southwestern Medical \\ Center at Dallas, Dallas, TX 75390, USA \\ * Correspondence: ian.corbin@utsouthwestern.edu; Tel.: +1-214-645-7044; Fax: +1-214-645-2744 \\ + These authors contributed equally to this work.
}

Received: 6 November 2019; Accepted: 4 December 2019; Published: 15 December 2019

\begin{abstract}
Lipoproteins are a family of naturally occurring macromolecular complexes consisting amphiphilic apoproteins, phospholipids, and neutral lipids. The physiological role of mammalian plasma lipoproteins is to transport their apolar cargo (primarily cholesterol and triglyceride) to their respective destinations through a highly organized ligand-receptor recognition system. Current day synthetic nanoparticle delivery systems attempt to accomplish this task; however, many only manage to achieve limited results. In recent years, many research labs have employed the use of lipoprotein or lipoprotein-like carriers to transport imaging agents or drugs to tumors. The purpose of this review is to highlight the pharmacologic, clinical, and molecular evidence for utilizing lipoprotein-based formulations and discuss their scientific rationale. To accomplish this task, evidence of dynamic drug interactions with circulating plasma lipoproteins are presented. This is followed by epidemiologic and molecular data describing the association between cholesterol and cancer.
\end{abstract}

Keywords: nanoparticle; lipoprotein; cancer therapy; cancer imaging; cholesterol

\section{Introduction}

Effective cancer therapy remains a daunting challenge for modern oncology due to the complexities governing tumorigenesis, tumor metastasis, and the limitations associated with current therapies. Over the last three decades colloidal nanocarriers have been implemented in oncology with the promise of providing targeted cancer treatment [1-3]. To this end, a diverse array of nanoscale drug-carriers including synthetic (silica, polymers) and natural (lipids, proteins, oligosaccharides) platforms have been designed for cancer drug delivery [4,5]. Among the many investigated nanoparticle systems lipoprotein/lipoprotein-like nanocarriers have become an increasingly attractive and sought-after nanostructures for the delivery of anticancer agents (see Figure 1). Several reviews are available that highlight this unique delivery strategy [6-9]. Lipoproteins are the main transport system for important lipid molecules such as cholesterol and fatty acids in mammals. The compartmentalized organization of these carriers that enables the transport of native molecules, also makes them amenable for facile incorporation of exogenous compounds [10]. This strategy for cancer drug delivery is not new, in fact back in $1981 \mathrm{Gal}$ et al. proposed that low-density lipoproteins (LDL) could be used as a delivery vehicle for chemotherapeutics and radionucleotides in the management of gynecologic malignancies [11]. Since this citation, numerous researchers from various institutions have utilized lipoprotein-based particles to deliver diverse molecular cargo ranging from contrast media, photodynamic agents, cytotoxic anticancer drugs, small molecule inhibitors, to nucleic acid therapies. Many cell culture 
and preclinical animal studies have been published demonstrating the feasibility and efficacy of these lipoprotein carriers to transport diagnostic/therapeutic agents to tumors [9,12-17]. A few patient studies have even been reported where LDL particles were used to transport Vincristine and Technetium-99 radiolabel in patients with gynecologic and brain malignancies respectively $[18,19]$.

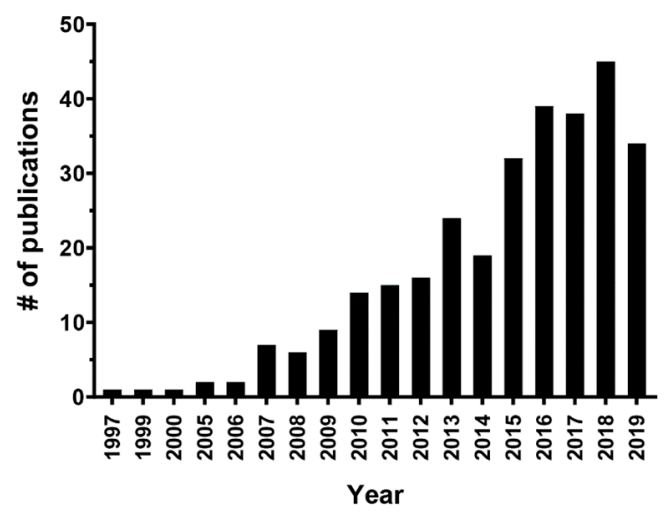

Figure 1. Frequency of publications on lipoproteins nanoparticles and cancer from 1998 to November 2019 in Pubmed using the search term "lipoprotein", "nanoparticle", "cancer". Exact search criteria: ("lipoproteins" or "lipoprotein") and ("nanoparticles" or "nanoparticle") and ("cancer" or "tumor").

The field of lipoprotein-mediated drug delivery has made numerous advances over the last several years. We have seen the transition from directly using isolated plasma lipoproteins for drug transport to the preferential employment of semi or fully synthetic lipoprotein-based nano vehicles. These nanostructures are typically formulated with natural apoproteins, recombinant apoproteins, synthetic apo-mimetic peptides, commercial lipids, and/or predetermined cargo [20]. This flexibility allows for strict control on ratio and structure of compounds incorporated into the nanoparticle, the size and dimensions of the lipoprotein carrier, thus regulating the physicochemical properties to enable more specific targeting while retaining many of the advantages of the natural lipoproteins. The delivery of nucleic acids with lipoprotein delivery systems (in particular synthetic high density lipoprotein (HDL) carriers) has become an increasingly popular way of performing gene therapy (RNAi, etc.) $[14,15,21]$. HDL's natural interaction with SR-B1 provides a means of direct cytosolic delivery of nucleic acid into the target cell. This provides a unique advantage over other particulate delivery system which are significantly hindered by endo-lysosomal trapping. A third and exciting advancement in recent years has been the expanded repertoire of bioactive and contrast agents that can be formulated into the lipoprotein nano-platform. Medical agents ranging from small molecule inhibitors (e.g., Everolimus, Sorafinib) to unique diagnostic nanocrystals of gold, iron oxide, or quantum dots have shown to be efficiently transported by lipoprotein-based vehicles $[9,22-24]$. When this wide array of cargo is combined with the innovations of rerouting lipoproteins to alternate receptor targets, one greatly expands the preview of diagnostic, therapeutic and scientific applications for lipoprotein-mediated drug delivery $[25,26]$.

The rationale behind the tumor-targeting lipoprotein drug delivery approach has often been relegated to oversimplified explanation of increased demand for lipid building blocks needed for membrane synthesis. In many ways this is an incomplete justification for enlisting lipoproteins as drug delivery vehicles. In this review we will highlight several lines of scientific reasoning that support the strategy for lipoprotein mediated drug delivery in oncology. These rationales will include: (i) pharmacological evidence for natural drug-lipoprotein interactions in the mammalian vascular system; (ii) epidemiologic population studies documenting an association between serum cholesterol levels and cancer incidence; (iii) identification of molecular networks that demonstrate the bi-directional signaling between cholesterol and cancer. 


\section{Lipoproteins: Endogenous Lipid Delivery System}

Plasma lipoproteins are a heterogeneous population of macromolecular aggregates that transport neutral lipids (fat and cholesterol) though the vascular system and extracellular fluid compartments of the body. These spherical lipid-based complexes display a range of physio-chemical properties; however, they have a common structural organization consisting of an apolar core of triglycerides (TG) and cholesterol esters covered by a monolayer of phospholipids and free cholesterol. Interspersed throughout the phospholipid monolayer are specific amphipathic proteins (apolipoproteins) which span the lipid and surrounding aqueous environment (Figure 2). These apolipoproteins provide structural integrity to the framework of the lipoproteins, modulate enzyme activity, as well as serve as ligands for the lipoprotein recognition and cellular uptake [27].

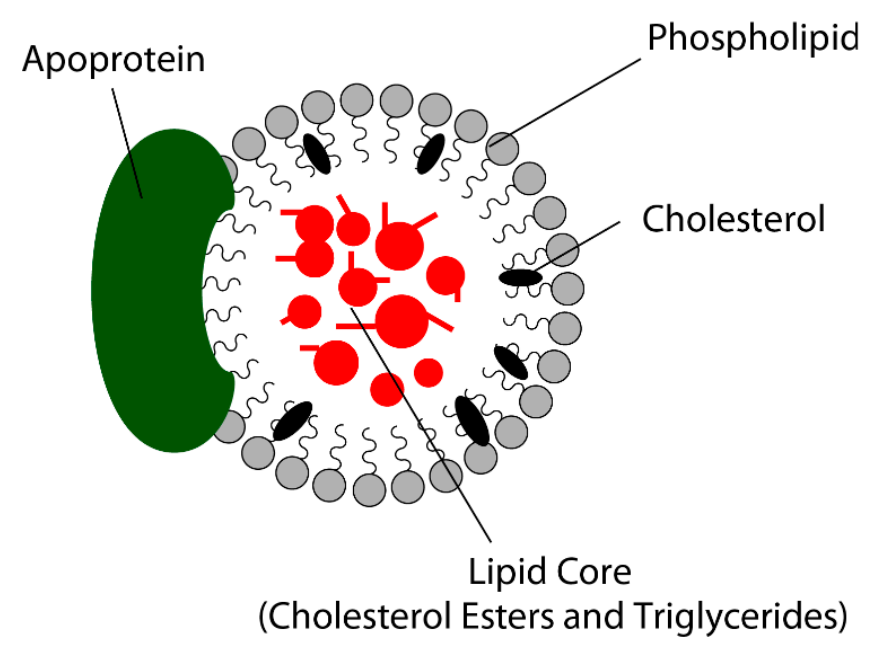

Figure 2. Typical Structure of Lipoproteins. Lipoprotein particles are made up of an apolipoprotein, a phospholipid monolayer with cholesterol particles intercalated in the membrane surrounding a lipophilic core consisting of TGs and cholesterol derivatives.

\section{Classification and Composition of Plasma Lipoproteins}

Plasma lipoproteins can be designated into various classes based on numerous physical parameters (e.g., electrophoretic mobility, diameter). The most commonly accepted classification is based on the density of the different lipoprotein species (see Table 1). Accompanying apolipoproteins and their functions are described in Table 2. According to this classification scheme the major density categories include: (i) Chylomicrons $(d<0.95 \mathrm{~g} / \mathrm{mL})$, these structures are TG-rich emulsion particles ( $80-88 \%$ by weight) containing apolipoprotein B48 that are synthesized by the intestine after a fatty meal. Chylomicrons are the largest particles in the lipoprotein family $(80 \mathrm{~nm}-1 \mu \mathrm{m}$ in diameter) and have the highest lipid to protein ratio; (ii) Very low density lipoproteins (VLDL, $d=0.95-1.006 \mathrm{~g} / \mathrm{mL}$ ), these lipoproteins are also TG rich particles, however, they are synthesized by the liver and contain apolipoprotein B100. They are smaller than chylomicrons (30-80 $\mathrm{nm}$ in diameter) and contain relatively less TG but more cholesterol and protein; (iii) Low density lipoproteins $(d=1.020-1.063)$ particles are formed by the intravascular removal of TGs from VLDL (lipoprotein lipase). The LDL core is predominately cholesterol ester molecules. LDL particles are the primary transport mechanism for the delivery of cholesterol to peripheral tissues, and account for $70-80 \%$ of circulating cholesterol in humans. Finally, (iv) high density lipoproteins $(d=1.063-1.210)$, these carriers are the smallest (6-12 nm in diameter) member of the lipoprotein family. Their core is mainly composed of cholesterol esters and they are composed of a relatively high proportion of protein ( $35-56 \%$ by weight) consisting primarily of apolipoprotein A1 and A2. The main physiological role of HDL is in the transport of unesterified cholesterol from peripheral tissues back to the liver. 
Table 1. Physiochemical Properties of Lipoproteins.

\begin{tabular}{ccccc}
\hline & Chylomicrons & VLDL & LDL & HDL \\
\hline Density $(\mathrm{g} / \mathrm{mL})$ & $<0.95$ & $0.95-1.006$ & $1.019-1.063$ & $1.063-1.210$ \\
\hline Diameter $(\mathrm{nm})$ & $>75$ & $30-80$ & $18-25$ & $7-14$ \\
Protein & $1-2$ & $8-10$ & $20-25$ & $52-60$ \\
TG & $80-95$ & $45-65$ & $4-8$ & $2-7$ \\
Cholesterol & $1-3$ & $4-8$ & $6-8$ & $3-5$ \\
Phospholipid & $3-6$ & $15-20$ & $18-24$ & $26-32$ \\
Cholesteryl ester & $2-4$ & $6-10$ & $45-50$ & $15-20$ \\
Electrophoretic mobility & - & Pre- $\beta$ & $\beta$ & $\mathrm{A}$ \\
\hline
\end{tabular}

Physiochemical Properties of Lipoproteins. VLDL—very low density lipoprotein; LDL-low density lipoprotein; HDL—high density lipoprotein; TAG—triacylglycerol. Expressed in \% dry weight.

Table 2. Properties of Major Human Apolipoproteins.

\begin{tabular}{ccccc}
\hline Apolipo-protein & $\begin{array}{c}\text { Mw } \\
\mathbf{( k D a})\end{array}$ & $\begin{array}{c}\text { Plasma Conc } \\
\mathbf{( m g / d L )}\end{array}$ & $\begin{array}{c}\text { Lipoprotein } \\
\text { Distribution }\end{array}$ & Function (s) \\
\hline ApoA1 & 29 & 130 & All HDL subclasses & cholesterol efflux; LCAT activation \\
ApoA2 & 17.4 & 40 & HDL-1, HDL-2, HDL-3 & Inhibition of apoA1 activity \\
ApoA4 & 44.5 & 15 & Chylomicrons & LCAT activation \\
ApoB48 & 241 & Transient & Chylomicrons & Chylomicron secretion \\
ApoB100 & 512 & $80-250$ & VLDL, LDL & VLDL secretion; LDL receptor ligand \\
ApoC1 & 6.6 & $3-6$ & HDL, LDL & LCAT activation \\
ApoC2 & 9 & $3-12$ & VLDL, HDLs & Activation of LPL \\
ApoC3 & 9 & 12 & VLDL, HDLs & Inhibition of apoC2 activity, VLDL uptake \\
ApoD & 19 & $10-12$ & HDL & Several Proposed \\
ApoE & 34 & $5-7$ & VLDL, HDL-1 & Cholesterol efflux; LDL receptor ligand \\
\hline
\end{tabular}

Properties of Major Human Apolipoproteins. VLDL-very low density lipoprotein; LDL-low density lipoprotein; HDL—high density lipoprotein; LCAT—lecithin-cholesterol acyltransferase; LPL—lipoprotein lipase.

\section{Drug Interactions with Plasma Lipoproteins}

Circulating lipoproteins are highly dynamic macromolecules whose composition and physical structure continually change under the constant flux of interchanging lipids and apolipoproteins. The interchange of lipid and apolipoprotein components between lipoprotein species operates in both fast and slow exchange regimes as passive diffusion and enzyme facilitated transport mediate these processes. During their transit time in the vascular system, other hydrophobic molecules may also associate with the lipoprotein complex. Prime examples of this are the numerous lipophilic vitamins and antioxidants that associate with lipoproteins in the plasma. By far the largest, and probably most important vitamin/antioxidant associated with lipoproteins is $\alpha$-tocopherol, which averages about 65 molecules per VLDL particle [28], 6 molecules per LDL particle [29], and HDL contains less than one tocopherol per particle [30]. Seminal work by Esterbauer et al. showed that other vitamins/antioxidants were present on LDL only in amounts of about $1 / 20$ to $1 / 300$ of that of $\alpha$-tocopherol. These vitamins/antioxidants include: $\gamma$-tocopherol, $\beta$-carotene, $\alpha$-carotene, lycopene, cryptoxanthin, canthaxanthin, phytofluene, and ubiquinol-10 [29]. These nutrients are also expected to be present at similar low ratios in the other lipoprotein classes.

Hydrophobic/basic drugs are another class of compounds that can bind to lipoproteins in the plasma. Drugs such as cyclosporine A, amiodarone, and amphotericin B are traditionally described in this context [31-33]. The biological significance of this association is that the pharmacokinetics, tissue distribution, and pharmacological activity of these drugs can be significantly modified upon binding to plasma lipoproteins [31,34-36]. This phenomenon is often overlooked in oncology, but many anticancer drugs do readily associate with circulating lipoproteins. The bulky polycyclic structure of many anticancer drugs enables them to easily cross cellular membranes reach their therapeutic target, but this chemistry also confers poor water solubility. The Biopharmaceutics Drug Disposition Classification System (BDDCS) categorizes drugs based on their water solubility and extent of 
metabolism (Figure 3) [37]. Class 2 drugs, those having low water solubility and extensive metabolism make up approximately $70 \%$ of new drugs in clinical trials and account for $30 \%$ of readily-available drugs [38]. In a survey of over 900 BDDCS classified drugs, 265 were categorized as Class 2 drugs and of these $34(\sim 13 \%)$ were identified as anti-cancer agents. Furthermore, studies by Yamamoto et al. indicate that class 2 drugs are more likely to associate with lipoproteins than other classes of drugs [39]. Poorly soluble drugs, like many vitamins/antioxidants, predominantly associate with lipoproteins as a result of thermodynamic pressure. Within the aqueous environment of plasma, poorly soluble compounds will seek other hydrophobic environments in order to minimize their contact with water molecules and maximize the intramolecular van der Waals interactions. Without such apolar environments for escape, poorly soluble compounds will self-aggregate in aqueous media which causes a high degree of ordered packing of water molecules around the hydrophobic compounds (i.e., a large positive Gibbs free energy driven by the adverse entropic effect on water). Thus, by associating with the hydrophobic compartments of circulating lipoproteins poorly soluble drugs can relieve the thermodynamic strain on the system and minimize the Gibbs free energy state.

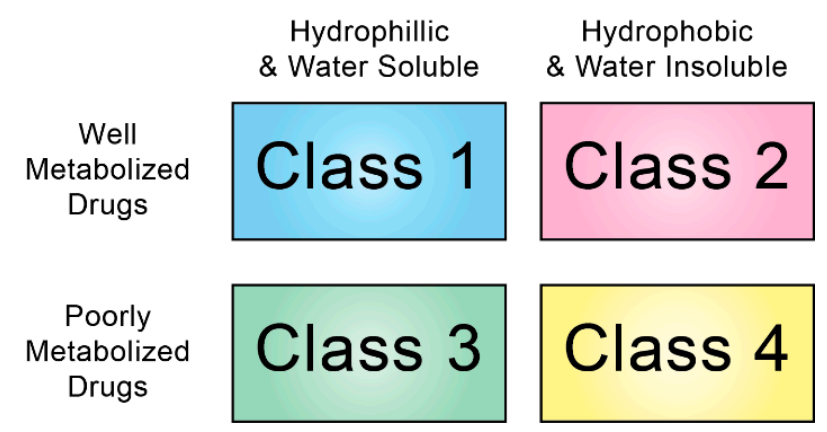

Figure 3. Four Quadrant System for Drug Classification. Biopharmaceutics Drug Disposition Classification System as proposed by $\mathrm{Wu}$ and Benet [37].

Drugs may also associate with circulating lipoproteins through facilitated transport processes. This is mediated through by lipid transfer protein, often referred to as Cholesteryl Ester Transfer Protein (CETP). Other lipid transfer proteins have been reported for TG and phospholipid transport, however, CETP is the most studied and characterized transfer protein. CETP is a $74 \mathrm{kDa}$ protein responsible for the facilitated transfer of neutral lipids (CE, TG) between lipoprotein classes [40,41]. The crystal structure of CETP was recently, published, providing significant insight into the mechanism of lipid transfer [42]. The protein appears to form a tunnel extending between adjacent donor and recipient lipoprotein particles to facilitate the molecular transfer of lipids. The $60 \AA$ long hydrophobic tunnel has the capacity to concurrently ferry two cholesteryl ester molecules through its core [42]. The size and hydrophobicity of the tunnel suggest that indiscriminate neutral lipid binding could be possible and provides supporting evidence for the potential role of CETP in drug transport. Several lines of evidence have demonstrated the role of CETP in the transfer of amphotericin B, halofantrine and cyclosporine A between lipoprotein classes [43]. Similar processes are also anticipated to facilitate the transfer of poorly soluble anticancer drugs.

Alterations in plasma lipoprotein content and composition can also influence the extent that drugs associate with lipoproteins. Dyslipidemias (disruption in the normal distribution of lipid classes within plasma) can arise from disturbances caused by disease or medication. High levels of plasma LDL and VLDL will induce hypercholesterolemia and/or hypertriglyceridemia. In these conditions, LDL/VLDL can serve as a large depot for poorly soluble drugs. Conversely, in conditions where plasma lipoproteins are lowered, the plasma levels of poorly soluble drugs can be significantly reduced. The specific pharmacodynamic/pharmacokinetic perturbation drugs experience with dyslipidemia is dependent on multiple factors such as: hydrophobicity of the drug, the etiology of the dyslipidemia, tissue lipoprotein receptor expression, etc. As such, the therapeutic consequence of altered drug metabolism can be highly variable during dyslipidemia. 
A few studies have also described lipoprotein lipid composition as an important factor influencing drug association. Increases in the TG to total cholesterol ratio was first found to increase drug (cyclosporine) association solely in the VLDL fraction [44]. Later investigations found that increases in this lipid ratio also increased drug association in the HDL pools [45]. These findings suggest that TGs may better solubilize drugs in the lipoprotein core than cholesterol moieties. Further studies are needed to validate these observations.

Drug association can occur within the aploar core or the external, more polar compartment of the lipoprotein particle. The relative preference of a drug to move into the apolar core or polar surface is determined by the $\log \mathrm{P}$ (octanol/water partition coefficient) of the drug. Thus, hydrophobic drugs (high $\log \mathrm{P}$ value) readily partition into the lipoprotein core $[46,47]$. This is a favorable compartment for drug transport as (i) it is 'shielded' from the external environment until receptor recognition/cell uptake and (ii) the core carrying capacity is considerable. Based on endogenous core lipid molecules, VLDL can carry an estimated 15,000 molecules of cholesterol esters and TG, LDL 1500 molecules, and HDL2 (10 nm diameter) 109 molecules [48]. On the more polar exterior amphiphilic drugs will associate with the phospholipid surface layer. Hydrophilic segments of the drug will orient near the phospholipid head groups, while the hydrophobic portions of the drug will associate with 'buried' fatty acyl chains of the phospholipids [46]. The surface characteristics of the phospholipid layer can also influence the partitioning of amphiphile drugs in the lipoprotein membrane monolayer. The surface layer of lipoproteins (VLDL and LDL) coexist in a liquid-order phase (rich in sphingomyelin and cholesterol) and a liquid-disorder phase (rich in glycerophospholipids) [49]. The more fluid and dynamic state of the liquid-disordered phase is more conducive for drug association/incorporation than the former liquid-order phase [50]. The polar surfaces of lipoproteins also have associated amphiphilic proteins (apolipoproteins) that differ in characteristics and surface coverage (Table 2). Conceivably, a drug could bind to a specific site on the apolipoprotein, analogous to albumin-drug binding. However, no specific examples of this type of interaction have been observed to date.

The natural drug interactions and the compartmentalized organization of lipoproteins strongly support the strategy of utilizing lipoproteins as drug delivery vehicles. As such, the next logical step would be to actively preload or formulate lipoproteins to carry exogenous agents for cancer treatment or detection. Several excellent papers have been written describing the formulation of lipoproteins with therapeutic or diagnostic agents [51-56].

\section{Epidemiological Evidence for Lipoprotein and Cancer Relationship}

There is a long history of investigations in human subjects examining the association of cancer and serum cholesterol levels (the majority of which is transported in circulating lipoproteins). A representative list of studies in the field has been presented as Table 3. In the following section we will explore the epidemiological data from some of the major studies to further mine the dynamic association between cholesterol and cancer.

\section{Cholesterol and Cancer Risk}

The largest study to date comprised of a cohort of over 1.2 million participants who enrolled in the Korean National Health Insurance Corporation medical evaluation between 1992-1995 and underwent biennial routine medical exams [56]. The study population which consisted of 53,944 men and 24,475 women were later diagnosed with cancer within the median follow-up time of 12.7 years. The data on total serum cholesterol (TSC) was stratified as high $(>240 \mathrm{mg} / \mathrm{dL}$ ) or low $(<160 \mathrm{mg} / \mathrm{dL}$ ) and adjusted for factors like lifestyle, habits, and fitness levels and comparisons between the groups were made as it related to cancer incidence. The data showed that across all cancer types, incidence of disease had a negative correlation with total cholesterol levels when high vs. low cholesterol groups were compared across both sexes (males: $\mathrm{HR}=0.84 ; 95 \% \mathrm{CI}=0.81-0.86$; females: $\mathrm{HR}=0.91$; $95 \% \mathrm{CI}=0.8-0.95$ ). The study did a second inference excluding the patients who reported cancer within the first 5 years of study to exclude cases that might already have underlying cancers. Excluding patients 
from the first 5 years minimized the chances of including cases of cancer undiagnosed at the start of the study. The results of the analysis showed that the incidence was not affected much (males: HR $=0.87$; 95\% CI $=0.84-0.91$; females: $\mathrm{HR}, 0.94 ; 95 \% \mathrm{CI}=0.89-1.00$ ).

When the group looked at specific cancers, high TSC seemed to decrease the risk of liver cancer (males: $\mathrm{HR}=0.42 ; 95 \% \mathrm{CI}=0.38-0.45$; females: $\mathrm{HR}=0.32 ; 95 \% \mathrm{CI}=0.27-0.39$ ). However, since chronic liver disease can cause alterations in cholesterol metabolism, additional adjustments for liver health were made (ALT, AST hepatitis B surface antigen). The adjustments in assessments slightly attenuated the incidence (males: $\mathrm{HR}=0.60 ; 95 \% \mathrm{CI}=0.54-0.67$; females: $\mathrm{HR}=0.46 ; 95 \% \mathrm{CI}=0.24$ to $0.87)$, but did not alter the association with cholesterol dramatically. The incidence of stomach cancer (males HR $=0.87 ; 95 \% \mathrm{CI}=0.82-0.93$; females: $\mathrm{HR}=0.86 ; 95 \% \mathrm{CI}=0.77-0.97$ ) also seem to be slightly significant across both sexes. On the other hand, the report suggests a positive association with breast cancer $(\mathrm{HR}=1.17 ; 95 \% \mathrm{CI}=1.03-1.33)$ incidence in women and colon $(\mathrm{HR}=1.24 ; 95 \% \mathrm{CI}=1.07-1.44)$ and prostate cancer $(\mathrm{HR}=1.12 ; 95 \% \mathrm{CI}=1.03-1.33)$ in men. Excluding the early cases resulted a stronger correlation for breast cancer $(\mathrm{HR}=1.21 ; 95 \% \mathrm{CI}=1.04-1.41)$ and colon cancers $(\mathrm{HR}=1.28$; $95 \% \mathrm{CI}=1.06-1.56)$ in females.

The overall conclusion of this study indicates that generally across different cancers there was an inverse relationship between cancer and cholesterol. However, the authors do mention that the overall results were heavily skewed by the number of liver cancer cases compared to other cancer types. For site specific cancers, liver and stomach cancers showed negative correlation. While breast cancers in females showed a positive correlation along with colon and prostate cancer in men. The significant power of this study comes from the large size of participants and the range of cholesterol values. The study also collected data and accounted for mitigating factor such as lifestyle, health status along with presence of liver disease. This study also had a 14 year follow up period which gave enough room for exclusion of early onset cases to eliminate undiagnosed cancer cases at the start of the study making this study a true risk analysis in contrast to correlative studies.

In another large study consisting of a European cohort of 577,330 individuals who were followed between 1972-2005 [57]. In this population study, 38,978 individuals reported having cancer in the mean follow-up time of 11.7 years [57]. The results showed that overall, cancer incidence was slightly inverse correlated with TSC (males; $\mathrm{HR}=0.94 ; 95 \% \mathrm{CI}=0.88-1$, females $\mathrm{HR}=0.86 ; 95 \% \mathrm{CI}=0.79-0.93$ ). Among the site specific data presented for males liver/bile duct ( $\mathrm{HR}=0.14 ; 95 \% \mathrm{CI}=0.07-0.29$ ), pancreatic $(\mathrm{HR}=0.52 ; 95 \% \mathrm{CI}=0.33-0.81)$, non-melanoma of skin $(\mathrm{HR}=0.67 ; 95 \% \mathrm{CI}=0.46-0.95)$ and lymphatic/hematopoietic ( $\mathrm{HR}=0.68 ; 95 \% \mathrm{CI}=0.54-0.87)$ cancer showed significant inverse correlation. Similarly, in females, gallbladder (HR $=0.23 ; 95 \%$ CI: $0.08,0.62)$, breast (HR $=0.70 ; 95 \%$ CI: $0.61,0.81$ ), skin melanoma (HR $=0.61 ; 95 \%$ CI: $0.42,0.88)$, and lymphatic/hematopoietic (HR $=0.61 ; 95 \%$ CI: 0.44 , 0.83 ) also showed inverse correlation.

A study in the state of California between 1964-1972 consisted of a large participant pool of 160,000 men and women spanning several cancer types [58]. This study showed that maximum risk was associated with high cholesterol in males with lymphoma (HR $=1.72 ; 95 \% \mathrm{CI} 1.00-2.83)$ and females with cervical cancer ( $\mathrm{HR}=1.30 ; 95 \% \mathrm{CI} 1.03-1.62)$ when lowest quintiles were compared to the higher ones. Among other cancer groups, prostate, lung, and pancreas in males and melanoma, ovarian, and lung cancers in females show modest increased risk. In contrast, risk marginally decreased for colon, rectum, melanoma and bladder in males and uterine cancers and lymphomas among females. Breast cancer showed no association in the data. Overall this study suggested a slightly higher risk of cancer associated across sexes (males HR $=1.03$; 95\% CI 0.97-1.10; females HR $=1.16$; 95\% CI 1.04-1.29)

Overall, we see the majority of papers reporting an overall inverse correlation between cholesterol level and cancer incidence (Table 3). However, the hazard ratio for this correlation can be only characterized as marginal at best (Figure 4). Depending on the study, multiple site-specific cancers showed negative correlations. However, these relationships can also be classified as minor, apart from a few studies that report significant hazard ratios for liver cancer. In general, the hazard ratio associated with TSC levels were highly variable and hence provide minimal clinical predictive value for cancer. 


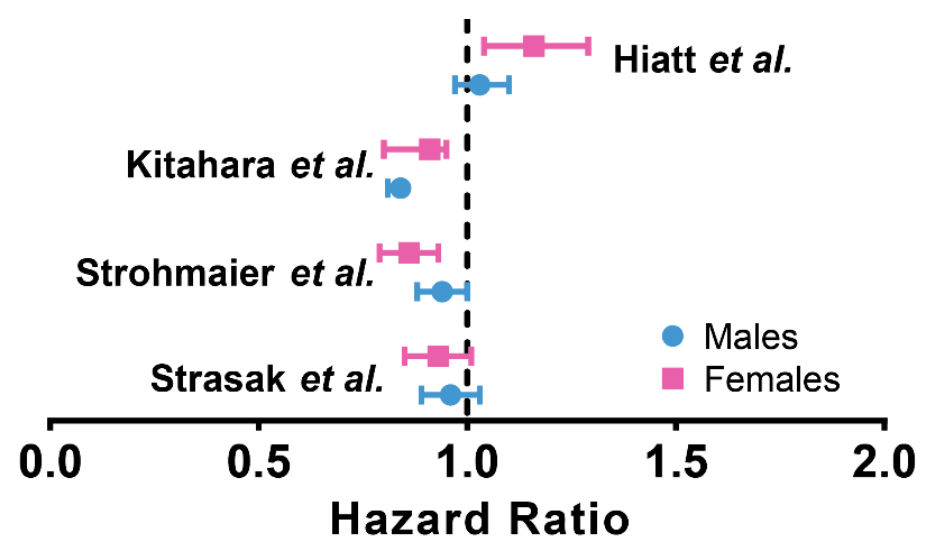

Figure 4. Hazard Ratios of Cholesterol-Cancer Association in Large Cohort Studies. Summary of hazard ratios in various large studies relating cancer and cholesterol. Note that majority of hazard ratio values are close to 1 .

In a sub-analysis of the European study consisting of 172,210 Austrian participants that were studied from 1985-2003 to determine the relationship between cholesterol and cancer risk in short term ( $<5$ months) and long term ( $>5$ months) [59]. In short term analysis, Strasak et al. observed a striking inverse correlation for overall cancer with compelling hazard ratios (males $\mathrm{HR}=0.58$; $95 \% \mathrm{CI}=0.43-0.78$ ); females HR $=0.69 ; 95 \% \mathrm{CI}=0.49-0.99$ ). Conversely, after 5 months, they reported low levels of risk similar to the previously discussed studies. For males the HR was 0.96 (95\% CI 0.89-1.03) and for females HR was 0.93 (95\% CI 0.85-1.01). This pronounced difference in hazard ratio for the short-term cohort can be attributed to "the preclinical effect" of cancer. The "preclinical effect" of cancer was proposed by McMichael et al. who stated that in "metabolic consequences of preexisting, undetected, cancer may be the cause of low serum cholesterol in those individuals at the time of their entry into the study" [60]. Thus, for true cancer-cholesterol risk studies, the hazard ratio can be skewed by patients who have undiagnosed cancer at the start of the study. This phenomenon can be seen in many of the cholesterol-cancer risk assessment studies. Additional studies by Hiatt et al. showed a strong pre-clinical effect among American patients who were diagnosed with cancer within two years of the study [58]. The overall relative risk for males increased approximately 2-fold among patients with the lowest cholesterol levels. Males with prostate, lung, and colon cancer showed the most striking increases in relative risk (3-fold, 2-fold, and 2-fold, respectively). Females with the lowest cholesterol levels also showed a slight increase in overall relative risk. Patients with carcinoma of the lung, colon, and uterine cancers displayed the highest levels of risk (3-fold, 2-fold, and 2-fold, respectively). Interestingly, when exclusion periods were extended out to 5 years, as in the Korean and the European study, the pre-clinical effect was not observed.

Table 3. Major Studies Showing Cancer and Lipoprotein Correlations.

\begin{tabular}{|c|c|c|c|c|}
\hline & Author & Year & Cancer Site & Major Conclusions \\
\hline 1 & Miller, S. R., et al. [61] & 1981 & Colon & Colon cancer patients had TSC $<$ Controls \\
\hline 2 & Vitols, S., et al. [62] & 1985 & Blood & $\begin{array}{l}\text { LDLR expression was high in leukemic cells. TSC levels } \\
\text { back to normal after chemotherapy }\end{array}$ \\
\hline 3 & Peterson, C., et al. [63] & 1985 & Blood & \\
\hline 4 & Budd \& Ginsberg [64] & 1986 & Blood & $\begin{array}{l}\text { TSC, LDLC \& HDLC lower in patients than controls. } \\
\text { TSC, LDLC and HDLC back to normal during remission }\end{array}$ \\
\hline 5 & Neugut, A. I., et al. [65] & 1986 & GI & TSC-Patient $<$ Controls \\
\hline 6 & Bani, I. A., et al. [66] & 1986 & Breast & TSC - Patient > Control. HDLC-Patient < Controls \\
\hline 7 & Reverter, J. C., et al. [67] & 1988 & AML & $\begin{array}{l}\text { LDLR expression was high in leukemic cells. TSC levels } \\
\text { back to normal after chemotherapy }\end{array}$ \\
\hline 8 & Marini, A., et al. [68] & 1989 & Blood & TSC-Patient $<$ Controls \\
\hline 9 & Rudling, M. J., et al. [69] & 1990 & Head & LDLR activity on tumor high \\
\hline 10 & Dessi, S., et al. [70] & 1991 & Blood & $\begin{array}{l}\text { HDLC patients }<\text { Controls. HDLC levels inversely } \\
\text { correlated with cell proliferation. }\end{array}$ \\
\hline
\end{tabular}


Table 3. Cont.

\begin{tabular}{|c|c|c|c|c|}
\hline & Author & Year & Cancer Site & Major Conclusions \\
\hline 11 & Shokumbi, W. A., et al. [71] & 1991 & Blood (ALL) & HDLC patients $<$ Controls \\
\hline 12 & Kritchevsky, S. B., et al. [72] & 1991 & Multiple & TSC decreased in patients before diagnosis \\
\hline 14 & Dessi, S., et al. [74] & 1992 & Lung & Tumor had 2-fold cholesterol. HDLC patients $<$ controls \\
\hline 15 & Umeki, S. [75] & 1993 & Lung & TSC and HDLC patients $<$ controls \\
\hline 16 & Bayerdorffer, E., et al. [76] & 1993 & Colorectal & $\begin{array}{c}\text { HDLC patients < controls; LDLC VLDLC patients }> \\
\text { Controls }\end{array}$ \\
\hline 17 & Potischman, N., et al. [77] & 1994 & Cervical & TSC in patients Stage I $>$ Stage II $>$ Stage IV \\
\hline 18 & Baroni, S., et al. [78] & 1994 & Blood (ALL) & $\begin{array}{l}\text { TSC HDLC patients < controls. Complete remission } \\
\text { correlated with increase in TSC and HDLC }\end{array}$ \\
\hline 19 & Kokoglu, E., et al. [79] & 1994 & Breast & $\begin{array}{l}\text { TSC VLDLC patients < controls. HDLC LDLC Stage IV } \\
<\text { Stage I patients. VLDL Stage IV > Stage I Patients }\end{array}$ \\
\hline 20 & Juliusson, G., et al. [80] & 1995 & Blood (HCL) & TSC LDLC inversely correlated with tumor burden \\
\hline 24 & Grieb, P., et al. [84] & 1999 & Brain & No reduction in TSC \\
\hline 25 & Siemianowicz, K., et al. [85] & 2000 & Lung & TSC Patients $<$ Controls \\
\hline 26 & Siemianowicz, K., et al. [86] & 2000 & Lung & No difference in LDLC \\
\hline 27 & Fiorenza, A. M., et al. [87] & 2000 & Multiple & TSC LDLC HDLC patients < Controls \\
\hline 28 & Abiaka, C., et al. [88] & 2001 & Multiple & TSC patients $<$ Controls \\
\hline 29 & Caruso, M. G., et al. [89] & 2001 & Colorectal & $\begin{array}{l}\text { LDLR protein and mRNA detected on tumor tissue. } \\
\text { LDLR mRNA higher in tumors not expressing protein }\end{array}$ \\
\hline 30 & Tomiki, Y., et al. [90] & 2004 & GI & TSC LDLC patients $<$ Controls \\
\hline 31 & Michalaki, V., et al. [91] & 2005 & Multiple & HDLC patients $<$ Controls in Breast Cancer \\
\hline 32 & Muntoni, S., et al. [92] & 2009 & Multiple & HDLC patients $<$ Controls \\
\hline 33 & Li, X., et al. [93] & 2018 & Breast & TSC HDLC LDLC patients $<$ Controls \\
\hline
\end{tabular}

While the risk to develop cancer from cholesterol is modest at best, after the onset of cancer, cholesterol levels are profoundly affected.

\section{Cholesterol Levels During Cancer}

There are several site-specific cancer studies showing relationships of cholesterol levels with different stages of cancer progression. Dessi et al. [70], while studying several hematologic malignancies, found a decrease in HDL-C in patient vs. control samples. They also report a negative correlation between cell proliferation based on clinical severity of the disease and serum HDL-C. Among solid tumors, hypocholesteremia was also seen by Umeki et al. in non-resectable lung cancer patients [75]. In addition, Dessi et al. [74], showed increased cholesterol in surgically removed tumoral tissue and a concomitant lower serum HDL-C in the lung cancer cohort. The study also found a 2-fold increase in free cholesterol and 3.5-fold increase in esterified cholesterol in the tumor compared to normal tissues. The esterified form of cholesterol is the primary means of cholesterol storage in rapidly dividing cells to provide an immediate reservoir of cholesterol for new cell membranes [74]. These two studies collectively show that tumors actively accumulate cholesterol leading to lower TSC. Miller and colleagues studied TSC and HDL-C in colon cancer as it progresses from stage A to D (Duke's Staging system) and saw decreasing levels as the disease advanced (Figure 5) [61]. This overall relationship between cholesterol and cancer was dissected further by Kokoglu et al. in the setting of breast cancer. They showed lower cholesterol levels in Stage I patients $(187.3 \mathrm{mg} / \mathrm{dL}$ vs. $201.4 \mathrm{mg} / \mathrm{dL}$ in healthy controls) and showed further depletion of TSC in Stage IV $(159.7 \mathrm{mg} / \mathrm{dL})$ [66]. Similar stage related decrease in TSC was also seen in cervical cancer patients [77]. Potischman et al. observed that patients at Stages I and II had a mean TSC level of $160 \mathrm{mg} / \mathrm{dL}(95 \% \mathrm{CI}=154-166 \mathrm{mg} / \mathrm{dL})$ while those in stage III and IV had TSC mean of $151 \mathrm{mg} / \mathrm{dL}(95 \%$ CI $=144-157 \mathrm{mg} / \mathrm{dL})$ and $148 \mathrm{mg} / \mathrm{dL}$ (95\% CI $=130-167 \mathrm{mg} / \mathrm{dL})$, respectively. This negative correlation between cancer progression and 
cholesterol is most striking when we study the relationship during metastasis or stage IV. In a study by Kritchevsky et al. [72], patients with distant metastasis had lower TSC and LDL-C than patients with more localized disease. These observations can be explained by the fact that as cancer progress towards metastasis in stage III and Stage IV, the proliferative activity and tumor burden increase further exasperating the demand for cholesterol. Cancer cells meet this demand by increasing cholesterol uptake from their environment through upregulating lipoprotein receptors like LDLR. Accompanying the higher LDLR activity in tumor tissues, both Vitols [62] and Peterson [63] reported lower TSC in hematological and solid tumors respectively. These findings support the notion that cancer induced hypocholesteremia may be the result of tumor sequestering of plasma cholesterol.

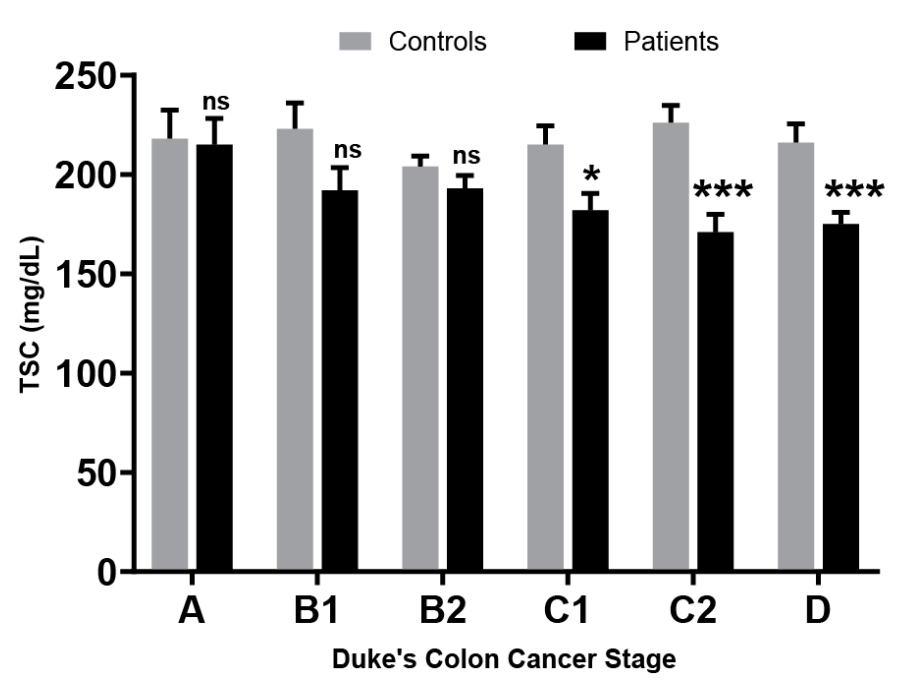

Figure 5. Total serum cholesterol levels observed by Miller et al. in colon cancer patients vs. controls. Error bars denote Standard Deviation. $p$ values for paired t-test ${ }^{*}=<0.05,{ }^{* * *}=<0.001$. ns = not significant.

\section{Cholesterol Levels Following Cancer Treatment}

Given that established cancers induce hypocholesteremia, effective anti-cancer treatments should reverse this lipid disturbance. Indeed, Vitols et al. reported that plasma levels of cholesterol increased as patients responded to chemotherapy that diminished the count of leukemic cells [62]. Additionally, a case study in the above-mentioned paper reported that when leukemic cells were removed from a patient by leukapheresis, the LDL-C was normalized. Alexopoulos et al. also reported increases in TSC and LDL-C after patients with varying types of cancer went through chemotherapy [73]. The overall change in TSC across all cancer types increased from $190 \pm 45 \mathrm{mg} / \mathrm{dL}$ pre-treatment to $215 \pm 50 \mathrm{mg} / \mathrm{dL}$ post treatment. The normalized TSC levels were maintained in patients throughout remission. Similar results were also reported in several other studies in hematologic and solid tumors [78,82,92].

In summary, these studies show a direct association and causality between tumor burden and the observed alterations in circulating cholesterol.

\section{Molecular Role of Cholesterol in Cancer}

Cholesterol is an essential building block for the construction of new cell membranes, and thus is necessary for rapidly proliferating cells. Cancer cells have altered composition and lipid metabolism when compared to normal cells owing to upregulated lipid and cholesterol biosynthesis $[95,96]$. One group has suggested that high cholesterol content in the lipid raft component of cancer cells poses a unique vulnerability for cancer cells [97]. This observation has led to the idea that certain drugs that perturb cholesterol homeostasis might be employed as potential treatments for cancer $[98,99]$. The therapeutic utility of inhibiting cholesterol biosynthesis or access is supported by the findings that oncogenic pathways drive cancer cells to accumulate more cholesterol. In contrast, there are 
also findings that cholesterol itself serves as signaling molecule to induce cancer aggressiveness. The following sections will examine these two seemingly contrasting observations.

\section{Cholesterol as an Oncogenic Driver}

In this section we will examine the evidence of cholesterol and its derivatives as signaling molecules. One such example of this phenomenon was demonstrated by Huang et al. when they showed that cholesterol directly stimulates Smoothened (SMO) leading to activation of Hedgehog (SHH) signaling. Smoothened is transmembrane G-protein coupled receptor protein that is normally repressed by the tumor suppressor Patched (PTCH1). When Hedgehog signaling is activated, Smoothened transduces signaling, leading to activation of GLI transcription factors that stimulate cancer cell growth [100]. Huang et al. further showed that Smoothened is activated by cholesterol and various cholesterol derivatives, such as oxysterols, which are naturally occurring oxidized forms of cholesterol [101]. While many of these molecules have cellular concentrations below the $\mathrm{EC}_{50}$ dose to activate Smoothened; in certain cases, such as cancer, cholesterol itself may be able to activate Smoothened. It remains unclear whether cholesterol mediated activation of Hedgehog signaling is enough to drive tumorigenesis, or if it simply facilitates tumor progression.

Cholesterol also plays a role in activating other G-protein coupled receptors (GPCRs). Guixà-González et al. showed that cholesterol binds directly to the Adenosine $A_{2 A}$ GPCR [102]. This group further suggested that cholesterol plays a role in allosteric regulation of GPCRs and could potentially even activate signaling. In a recent paper by Moon et al. cholesterol signaling through GPCRs was implicated in androgen independent metastasis in prostate cancer [103].

It is well documented that cholesterol and its derivatives can activate both the Estrogen Receptor (ER) and Estrogen Related Receptors (ERRs) [104,105]. The Estrogen Receptor is known as a promiscuous receptor and has many ligands, several of which are derived from cholesterol including its primary ligand estrogen [106]. Nelson et al. showed that a specific derivative of cholesterol, 27-hydroxycholestrol (27HC) serves as an ER ligand in the context of breast cancer [105]. This group further showed that 27HC is enough to drive the growth of MCF7 xenograft tumors. Nelson et al. then showed that the enzyme that makes 27HC (CYP27A1) is correlated with higher tumor grade and metastasis. While Nelson et al. suggested that inhibiting synthesis of 27HC may prove to be a potential therapy for breast cancer, this molecule is probably not the primary driver in breast cancer, but is likely to be a method that contributes to resistance to therapy as suggested by Simigdala et al. [107].

Estrogen Related Receptors (ERRs) are a family of nuclear receptor transcription factors that are not as well studied in the context of cancer. The most well understood receptor in this family is ERR $\alpha$; with ERR $\beta$ and ERR $\gamma$ being less well studied [104]. One group, Wei et al. showed that one of many ligands for ERR $\alpha$ is cholesterol [108]. They observed that when cells are depleted of cholesterol, ERR $\alpha$ transcriptional activity disappears. Furthermore, they showed that statin treatment and resulting cholesterol depletion shut down ERR $\alpha$ transcription. ERR $\beta$ and ERR $\gamma$ do not yet have an identified natural ligand, but do bind synthetic ligands such as 4-hydroxy-tamoxifen (4-OHT) and bisphenol-A [109,110]. Not much is known about the relationship between cholesterol and ERR $\beta$ or ERR $\gamma$, but due to sequence homology with ERR $\alpha$ it is likely that cholesterol or its derivatives have some ability to activate these two receptors.

In summary, cholesterol can activate three different signaling pathways (GPCRs, ER, and ERRs) in cancer as shown in Figure 6.

Cholesterol also forms a major component of lipid rafts, which is central to many processes in signal transduction [111]. Lipid rafts are generally small ranging in size from 10-200 nm, and are densely packed with cholesterol, proteins, and sphingolipids [112]. Lipid rafts are generally represented as floating collections of various signaling proteins that can be transported to and from the cell membrane to facilitate signaling [113]. Many canonical drivers of cell proliferation have signaling that has been localized to lipid rafts including Epidermal Growth Factor Receptor (EGFR), Insulin-like growth factor receptor (IGFR), Hedgehog, and H-RAS [113-115]. AKT which functions downstream of various 
receptors in cancer, also has been localized to lipid rafts, and it has been shown that AKT signaling stops when cellular cholesterol is depleted [99]. Concurrently, it has also been shown that HER2 signaling is localized to cholesterol rich domains in cell membranes, suggesting that cholesterol plays a role is helping facilitate HER2 dependent oncogenic signaling [95]. Thus, lipid rafts may present a good target to treat cancer cell as suggested by Li et al. [97].

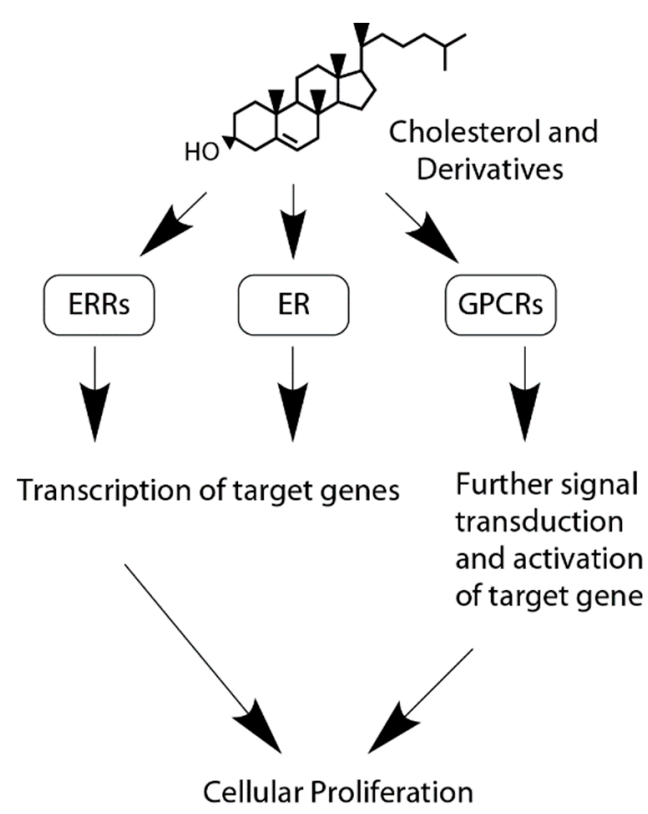

Figure 6. Signaling functions of cholesterol and cholesterol derivatives. Cholesterol and its derivatives interact with estrogen related receptors (ERRs), the estrogen receptor (ER), and G-protein coupled receptors (GPCRS) to induce more oncogenic signaling mediated by transcriptional activation of further downstream signaling.

Another potential mechanism whereby cholesterol and lipids can promote carcinogenesis through lipid peroxidation. Oxygen mediated breakdown of unsaturated lipids is known to create many reactive and potentially mutagenic substances. Tseng et al. showed that a high cholesterol diet can lead to induction of lipid peroxidation that can help contribute to carcinogenesis [116]. While the study did not go into the exact mechanism of how lipid peroxidation induces cancer, the majority of lipids and cholesterol derivatives have been shown to undergo lipid peroxidation [117]. One cholesterol derivative 7-dihydro-cholesterol is particularly vulnerable to auto-oxidation, and likely plays a part in cholesterol mediated mutagenesis. More recent studies have proposed that oxidized low-density lipoprotein may be to blame [118]. One such example by Khaidakov and Mehta showed that stimulation of mammary epithelial cells with oxidized LDL increased expression of miR21, which then inhibits function of PTEN resulting in activation of AKT [119].

\section{Cholesterol Accumulation Driven by Oncogenic Signaling}

Cholesterol homeostasis in cells is regulated by SREBP1 and SREBP2 proteins belong to the Sterol Regulatory Binding Protein family (SREBPs), which are transcription factors that respond to intracellular levels of cholesterol [120]. SREBP1 was shown to regulate levels of LDLR in cells as do other proteins of the SREBP family who perform similar functions [121]. Subsequent observation by Porstmann et al. found that that SREBPs are regulated by the Molecular Target of Rapamycin Complex 1 (mTORC1) as a result of AKT oncogenic signaling [122]. This finding suggests that mTORC1 serves as a central regulator of cancer cell metabolism including cholesterol import and biosynthesis. mTOR signaling is overactive in many cancers, including breast, prostate, lung, liver, and kidney cancers. As such, this mechanism of upregulating cholesterol biosynthesis is likely prevalent in these 
cancers [123]. Later studies also report this, Yue et al. reported that PTEN loss results in unabated PI3K/AKT signaling that induces the accumulation of cholesterol [124]. Yue et al. further reported that patient samples showing high cholesterol accumulation displayed a more aggressive phenotype. In another context, neuregulin activated ERBB4 (HER4) was shown to induce activity of SREBP-2 which resulted in higher low-density lipoprotein uptake [125]. Given that ERBB4 is one of many upstream regulators of AKT signaling, the cholesterol enriching tumor phenotype should be common in many ERBB4 expressing cancers [126]. In many cancers AKT seems to serve as a master regulator of cellular metabolism; including both of catabolic (cellular energetics) and anabolic processes, such as cholesterol biosynthesis (Figure 7). Interestingly, AKT signaling can be abated by using simvastatin which would suggest that cholesterol pays a role in allowing AKT signaling to proceed [99]. This could be explained simply by the fact that cholesterol forms a large component of lipid rafts and that AKT signaling is localized to lipid rafts [127]. While this may be the simple explanation, the relationship between cholesterol and AKT signaling is probably more complex, owing to the findings that cholesterol serves as a signaling molecule.

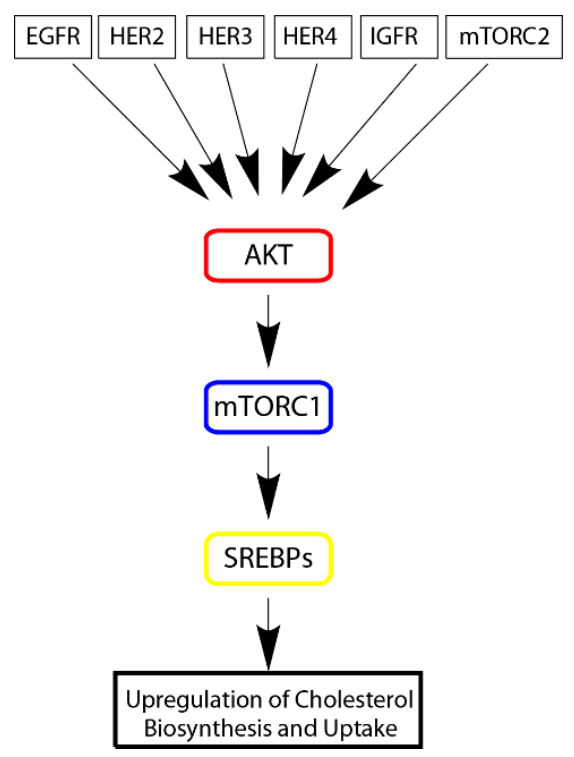

Figure 7. AKT, Master Regulator of Cholesterol Accumulation. AKT plays a central role in receiving signals from various oncogenic drivers (Epidermal Growth Factor Receptor (EGFR), HER2, HER3, HER4, Insulin-like growth factor receptor (IGFR), and mTORC2) and then activating Molecular Target of Rapamycin Complex 1 (mTORC1) which then leads to activation of Sterol Regulatory Binding Protein (SREBPs) that then upregulate cholesterol synthesis and uptake.

\section{Cholesterol Feedback Loop, Both Sides of the Same Process}

Within the cancer cell, cholesterol can initiate signaling functions through GPC transmembrane receptors, Hedgehog, ERRs, and ER. The idea of a cholesterol feedback loop was proposed by He and colleagues in 2017 in the context of hepatocellular carcinoma [128]. They proposed that inflammatory signaling mediated by NF- $\mathrm{KB}$ induces cholesterol accumulation by activating transcription of SREBP-2, thereafter cholesterol further activates NF- $\mathrm{kB}$ resulting in more pro-inflammatory signaling. Thus, once oncogenic signaling begins it starts cellular proliferation which enhances the need for more cholesterol. The acquired cholesterol is then able to drive the cell towards a more malignant phenotype (Figure 8.). A similar process seems to occur with AKT signaling owing to the finding that AKT signaling can be shut down by inhibiting cholesterol biosynthesis with a statin and by activation of the liver $X$ receptor $[99,129,130]$. Furthermore, in HER2 enriched breast cancer, cholesterol seems to stabilize the HER2 receptor in the membrane suggesting another method that cholesterol can use to induce more oncogenic signaling [95]. Thus, this positive feedback loop seems to occur in multiple cancers, 
indicating that this may be a general molecular strategy of potentiating tumor growth and metastasis. It also follows that interventions that take advantage of a tumor's need for cholesterol may be a useful therapeutic approach for eliminating cancer cells.

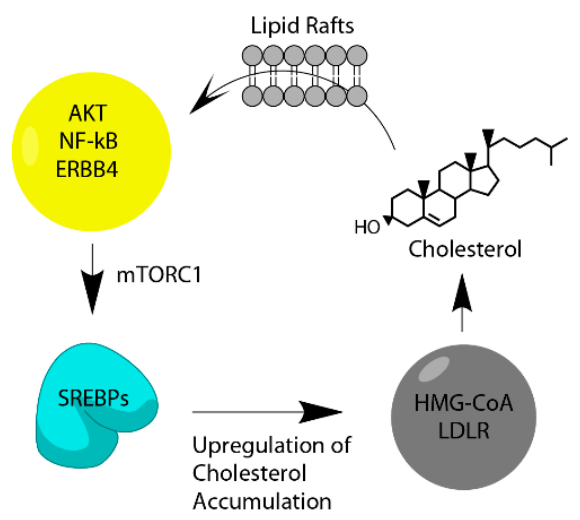

Figure 8. Cholesterol Feedback Loop. AKT signaling drives increases in cholesterol biosynthesis and uptake mediated by mTORC1 and SREBPs which leads to increased levels of cholesterol that activates more oncogenic signaling leading to a more aggressive tumor.

\section{Conclusions}

In addition to the delivery of natural lipids, lipoproteins may also be used to facilitate the systemic transport of drugs or diagnostic agents. This notion of a lipoprotein-mediated drug delivery system is supported by multiple lines of evidence in this review. Pharmacological studies have shown that thermodynamic forces naturally drive the interaction and association of circulating lipophilic and amphiphilic drugs with lipoproteins. Further supporting this association, is the compartmentalized organization of the lipoprotein readily facilitates the incorporation of exogenous molecules into its structure. Surprisingly enough, malignant cells avidly acquire plasma lipoproteins from the circulation. Clinical epidemiologic data among patients with diagnosed cancer strongly demonstrate the high sequestering of plasma cholesterol/lipoproteins by tumors. Furthermore, these clinical findings are corroborated by molecular data that substantiates that cholesterol uptake and accumulation in tumors is driven by the oncogenic driver AKT. Conversely, cholesterol has also been shown to serve as a key signaling molecule in tumor progression. Thus, in a reciprocal positive feedback loop cholesterol accumulation further drives tumor aggression. Collectively, these finding provide strong scientific reasoning for the adoption of lipoproteins as drug delivery vehicles for cancer treatment and detection.

Author Contributions: J.C., review design; draft article; critical revision of content, J.B. Review design; draft article; critical revision of content. I.R.C., contribution to conception and design; analysis and interpretation of data; draft article and critical revision; final approval for publication; accountable for all aspects of work. J.C. and J.B. contributed equally to this review.

Funding: This work was supported in part by NCI, National Institutes of Health (NIH), Grant R01CA215702, Society of Interventional Radiology Foundation Dr. Ernest J. Ring Academic Development Grant, and the METAvivor research award. Author JB was supported by NIH Training Grant (T32CA124334-13).

Conflicts of Interest: The authors declare that they have no conflict of interest with the contents of this article. The content is solely the responsibility of the authors and does not necessarily represent the official views of the National Institutes of Health.

\section{Abbreviations}

27HCL

$4-\mathrm{OHT}$

AKT

ALL

AML

BDDCS
27-Hydroxycholestrol 4-Hydroytamoxifen Rac-Alpha Serine/Threonine-Protein Kinase Acute Lymphocytic Leukemia

Acute Myeloid Leukemia

Biopharmaceutics Drug Disposition Classification System 


\begin{tabular}{|c|c|}
\hline CE & Cholesterol Ester \\
\hline CETP & Cholesteryl Ester Transfer Protein \\
\hline CI & Confidence Interval \\
\hline DHA & Docosahexaenoic Acid \\
\hline EGFR & Epidermal Growth Factor Receptor \\
\hline ER & Estrogen Receptor \\
\hline ERBB4/HER4 & Epidermal Growth Factor Receptor Family Member 4 \\
\hline ERRS & Estrogen Related Receptors \\
\hline GLIs & glioma-associated oncogene \\
\hline GPCRS & G-Protein Coupled Receptor \\
\hline GTPase & Guanosine Triphosphate Hydrolase Enzyme \\
\hline HDL & High Density Lipoprotein \\
\hline HDL-C & High Density Lipoprotein Cholesterol \\
\hline HER2 & Epidermal Growth Factor Receptor Family Member 2 \\
\hline HR & Hazard Ratio \\
\hline IGFR & Insulin Growth Factor Receptor \\
\hline IQGAP1 & Ras Gtpase-Activating-Like Protein 1 \\
\hline LCAT & Lecithin-Cholesterol Acyltransferase \\
\hline LDL & Low Density Lipoprotein \\
\hline LDL-C & Low Density Lipoprotein Cholesterol \\
\hline LDLR & Low-Density Lipoprotein Receptor \\
\hline LOX-1 & Lectin-Type Oxidized Low Density Lipoprotein Receptor 1 \\
\hline LPL & Lipoprotein Lipase \\
\hline $\mathrm{mg} / \mathrm{dL}$ & Milligram Per Deciliter \\
\hline mTORC1/2 & Molecular Target of Rapamicin Complex 1 and 2 \\
\hline PI3K & Phosphoinositide 3-Kinase \\
\hline PTCH1 & Patched \\
\hline PTEN & Phosphatase And Tensin Homolog \\
\hline $\mathrm{SHH}$ & Hedgehog \\
\hline SMO & Smoothened \\
\hline SREBPs & Sterol Regulatory Binding Protein Family \\
\hline TG & Triglycerides \\
\hline TSC & Total Serum Cholesterol \\
\hline VLDL & Very Low Density Lipoprotein Cholesterol \\
\hline
\end{tabular}

\section{References}

1. Ferrari, M. Cancer nanotechnology: Opportunities and challenges. Nat. Rev. Cancer 2005, 5, 161-171. [CrossRef] [PubMed]

2. Schroeder, A.; Heller, D.A.; Winslow, M.M.; Dahlman, J.E.; Pratt, G.W.; Langer, R.; Jacks, T.; Anderson, D.G. Treating metastatic cancer with nanotechnology. Nat. Rev. Cancer 2012, 12, 39-50. [CrossRef] [PubMed]

3. Bae, K.H.; Chung, H.J.; Park, T.G. Nanomaterials for cancer therapy and imaging. Mol. Cells 2011, 31, $295-302$. [CrossRef]

4. Xie, X.; Zhang, Y.; Li, F.; Lv, T.; Li, Z.; Chen, H.; Jia, L.; Gao, Y. Challenges and Opportunities from Basic Cancer Biology for Nanomedicine for Targeted Drug Delivery. Curr. Cancer Drug Targets 2019, 19, 257-276. [CrossRef] [PubMed]

5. Patra, J.K.; Das, G.; Fraceto, L.F.; Campos, E.V.R.; Rodriguez-Torres, M.d.P.; Acosta-Torres, L.S.; Diaz-Torres, L.A.; Grillo, R.; Swamy, M.K.; Sharma, S.; et al. Nano based drug delivery systems: Recent developments and future prospects. J. Nanobiotechnol. 2018, 16, 71. [CrossRef]

6. Ng, K.K.; Lovell, J.F.; Zheng, G. Lipoprotein-inspired nanoparticles for cancer theranostics. Acc. Chem. Res. 2011, 44, 1105-1113. [CrossRef]

7. Mahmoudian, M.; Salatin, S.; Khosroushahi, A.Y. Natural low- and high-density lipoproteins as mighty bio-nanocarriers for anticancer drug delivery. Cancer Chemother. Pharmacol. 2018, 82, 371-382. [CrossRef] 
8. Raut, S.; Dasseux, J.L.; Sabnis, N.A.; Mooberry, L.; Lacko, A. Lipoproteins for therapeutic delivery: Recent advances and future opportunities. Ther. Deliv. 2018, 9, 257-268. [CrossRef]

9. Thaxton, C.S.; Rink, J.S.; Naha, P.C.; Cormode, D.P. Lipoproteins and lipoprotein mimetics for imaging and drug delivery. Adv. Drug Deliv. Rev. 2016, 106, 116-131. [CrossRef]

10. Prassl, R.; Laggner, P. Molecular structure of low density lipoprotein: Current status and future challenges. Eur. Biophys. J. 2009, 38, 145-158. [CrossRef]

11. Gal, D.; Ohashi, M.; MacDonald, P.C.; Buchsbaum, H.J.; Simpson, E.R. Low-density lipoprotein as a potential vehicle for chemotherapeutic agents and radionucleotides in the management of gynecologic neoplasms. Am. J. Obstet. Gynecol. 1981, 139, 877-885. [CrossRef]

12. Corbin, I.R.; Ng, K.; Zheng, G. Lipoprotein-Based Nanoplatforms for Cancer Molecular Imaging. In Nanoplatform-Based Molecular Imaging; John Wiley \& Sons Inc.: Hoboken, NJ, USA, 2011; pp. 431-462. [CrossRef]

13. Firestone, R.A. Low-density lipoprotein as a vehicle for targeting antitumor compounds to cancer cells. Bioconjug. Chem. 1994, 5, 105-113. [CrossRef] [PubMed]

14. Nakayama, T.; Butler, J.S.; Sehgal, A.; Severgnini, M.; Racie, T.; Sharman, J.; Ding, F.; Morskaya, S.S.; Brodsky, J.; Tchangov, L.; et al. Harnessing a physiologic mechanism for siRNA delivery with mimetic lipoprotein particles. Mol. Ther. 2012, 20, 1582-1589. [CrossRef] [PubMed]

15. Huang, J.-L.; Jiang, G.; Song, Q.-X.; Gu, X.; Hu, M.; Wang, X.-L.; Song, H.-H.; Chen, L.-P.; Lin, Y.-Y.; Jiang, D.; et al. Lipoprotein-biomimetic nanostructure enables efficient targeting delivery of siRNA to Ras-activated glioblastoma cells via macropinocytosis. Nat. Commun. 2017, 8, 15144. [CrossRef]

16. Ujiie, H.; Ding, L.; Fan, R.; Kato, T.; Lee, D.; Fujino, K.; Kinoshita, T.; Lee, C.Y.; Waddell, T.K.; Keshavjee, S.; et al. Porphyrin-High-Density Lipoprotein: A Novel Photosensitizing Nanoparticle for Lung Cancer Therapy. Ann. Thorac. Surg. 2019, 107, 369-377. [CrossRef]

17. Li, H.; Marotta, D.; Kim, S.; Busch, T.M.; Wileyto, E.P.; Zheng, G. High Payload Delivery of Optical Imaging and Photodynamic Therapy Agents to Tumors Using Phthalocyanine-Reconstituted LDL Nanoparticles. J. Biomed. Opt. 2005, 10, 041203. [CrossRef]

18. Filipowska, D.; Filipowski, T.; Morelowska, B.; Kazanowska, W.; Laudanski, T.; Lapinjoki, S.; Akerlund, M.; Breeze, A. Treatment of cancer patients with a low-density-lipoprotein delivery vehicle containing a cytotoxic drug. Cancer Chemother. Pharmacol. 1992, 29, 396-400. [CrossRef]

19. Leppälä, J.; Kallio, M.; Nikula, T.; Nikkinen, P.; Liewendahl, K.; Jääskeläinen, J.; Savolainen, S.; Gylling, H.; Hiltunen, J.; Callaway, J. Accumulation of 99mTc-low-density lipoprotein in human malignant glioma. Br. J. Cancer 1995, 71, 383-387. [CrossRef]

20. Amin, A.R.; Amin, H.K. Lipoprotein Nanoparticles in Diagnosis and Treatment of Cancer. MOJ Drug Des. Dev. Ther. 2018, 2, 24.

21. Lin, Q.; Chen, J.; Zhang, Z.; Zheng, G. Lipid-based nanoparticles in the systemic delivery of siRNA. Nanomedicine 2014, 9, 105-120. [CrossRef]

22. Berney, E.; Sabnis, N.; Panchoo, M.; Raut, S.; Dickerman, R.; Lacko, A.G. The SR-B1 Receptor as a Potential Target for Treating Glioblastoma. J. Oncol. 2019, 2019, 1805841. [CrossRef] [PubMed]

23. Li, M.; Su, Y.; Zhang, F.; Chen, K.; Xu, X.; Xu, L.; Zhou, J.; Wang, W. A dual-targeting reconstituted high density lipoprotein leveraging the synergy of sorafenib and antimiRNA21 for enhanced hepatocellular carcinoma therapy. Acta Biomater. 2018, 75, 413-426. [CrossRef] [PubMed]

24. Fay, F.; Sanchez-Gaytan, B.L.; Cormode, D.P.; Skajaa, T.; Fisher, E.A.; Fayad, Z.A.; Mulder, W.J.M. Nanocrystal Core Lipoprotein Biomimetics for Imaging of Lipoproteins and Associated Diseases. Curr. Cardiovasc. Imaging Rep. 2013, 6, 45-54. [CrossRef] [PubMed]

25. Zheng, G.; Chen, J.; Li, H.; Glickson, J.D. Rerouting lipoprotein nanoparticles to selected alternate receptors for the targeted delivery of cancer diagnostic and therapeutic agents. Proc. Natl. Acad. Sci. USA 2005, 102, 17757-17762. [CrossRef] [PubMed]

26. Chen, W.; Jarzyna, P.A.; van Tilborg, G.A.; Nguyen, V.A.; Cormode, D.P.; Klink, A.; Griffioen, A.W.; Randolph, G.J.; Fisher, E.A.; Mulder, W.J.; et al. RGD peptide functionalized and reconstituted high-density lipoprotein nanoparticles as a versatile and multimodal tumor targeting molecular imaging probe. FASEB J. 2010, 24, 1689-1699. [CrossRef] [PubMed] 
27. Mahley, R.W.; Innerarity, T.L.; Rall, S.C.Jr.; Weisgraber, K.H. Plasma lipoproteins: Apolipoprotein structure and function. J. Lipid Res. 1984, 25, 1277-1294. [PubMed]

28. Parks, E.J.; Dare, D.; Frazier, K.B.; Hellerstein, M.K.; Neese, R.A.; Hughes, E.; Traber, M.G. Dependence of plasma $\alpha$-tocopherol flux on very low-density triglyceride clearance in humans. Free Radic. Biol. Med. 2000, 29, 1151-1159. [CrossRef]

29. Esterbauer, H.; Puhl, H.; Dieber-rotheneder, M.; Waeg, G.; Rabl, H. Effect of Antioxidants on Oxidative Modification of LDL. Ann. Med. 1991, 23, 573-581. [CrossRef]

30. Bowry, V.W.; Stanley, K.K.; Stocker, R. High density lipoprotein is the major carrier of lipid hydroperoxides in human blood plasma from fasting donors. Proc. Natl. Acad. Sci. USA 1992, 89, 10316-10320. [CrossRef]

31. Wasan, K.M.; Brazeau, G.A.; Keyhani, A.; Hayman, A.C.; Lopez-Berestein, G. Roles of liposome composition and temperature in distribution of amphotericin B in serum lipoproteins. Antimicrob. Agents Chemother. 1993, 37, 246-250. [CrossRef]

32. Yau, J.C.; Brunner, L.J.; Lopez-Berestein, G.; LeMaistre, C.F.; Luke, D.R. Therapeutic drug monitoring of cyclosporine-lipoprotein levels. Pharmacotherapy 1991, 11, 291-295. [PubMed]

33. Shayeganpour, A.; Lee, S.D.; Wasan, K.M.; Brocks, D.R. The influence of hyperlipoproteinemia on in vitro distribution of amiodarone and desethylamiodarone in human and rat plasma. Pharm. Res. 2007, 24, 672-678. [CrossRef] [PubMed]

34. McIntosh, M.P.; Porter, C.J.; Wasan, K.M.; Ramaswamy, M.; Charman, W.N. Differences in the lipoprotein binding profile of halofantrine in fed and fasted human or beagle plasma are dictated by the respective masses of core apolar lipoprotein lipid. J. Pharm. Sci. 1999, 88, 378-384. [CrossRef] [PubMed]

35. Rossignol, D.P.; Wasan, K.M.; Choo, E.; Yau, E.; Wong, N.; Rose, J.; Moran, J.; Lynn, M. Safety, pharmacokinetics, pharmacodynamics, and plasma lipoprotein distribution of eritoran (E5564) during continuous intravenous infusion into healthy volunteers. Antimicrob. Agents Chemother. 2004, 48, 3233-3240. [CrossRef] [PubMed]

36. Lacko, A.G.; Nair, M.; Paranjape, S.; Johnso, S.; McConathy, W.J. High density lipoprotein complexes as delivery vehicles for anticancer drugs. Anticancer Res. 2002, 22, 2045-2049. [PubMed]

37. Wu, C.Y.; Benet, L.Z. Predicting drug disposition via application of BCS: Transport/absorption/ elimination interplay and development of a biopharmaceutics drug disposition classification system. Pharm. Res. 2005, 22, 11-23. [CrossRef] [PubMed]

38. Benet, L.Z.; Broccatelli, F.; Oprea, T.I. BDDCS applied to over 900 drugs. AAPS J. 2011, 13, 519-547. [CrossRef]

39. Yamamoto, H.; Takada, T.; Yamanashi, Y.; Ogura, M.; Masuo, Y.; Harada-Shiba, M.; Suzuki, H. VLDL/LDL acts as a drug carrier and regulates the transport and metabolism of drugs in the body. Sci. Rep. 2017, 7, 633. [CrossRef]

40. Tall, A.R.; Abreu, E.; Shuman, J. Separation of a plasma phospholipid transfer protein from cholesterol ester/phospholipid exchange protein. J. Biol. Chem. 1983, 258, 2174-2180.

41. Pattnaik, N.M.; Montes, A.; Hughes, L.B.; Zilversmit, D.B. Cholesteryl ester exchange protein in human plasma isolation and characterization. Biochim. Biophys. Acta 1978, 530, 428-438. [CrossRef]

42. Qiu, X.; Mistry, A.; Ammirati, M.J.; Chrunyk, B.A.; Clark, R.W.; Cong, Y.; Culp, J.S.; Danley, D.E.; Freeman, T.B.; Geoghegan, K.F.; et al. Crystal structure of cholesteryl ester transfer protein reveals a long tunnel and four bound lipid molecules. Nat. Struct. Mol. Biol. 2007, 14, 106-113. [CrossRef] [PubMed]

43. Wasan, K.M.; Brocks, D.R.; Lee, S.D.; Sachs-Barrable, K.; Thornton, S.J. Impact of lipoproteins on the biological activity and disposition of hydrophobic drugs: Implications for drug discovery. Nat. Rev. Drug Discov. 2008, 7, 84-99. [CrossRef] [PubMed]

44. Gardier, A.M.; Mathe, D.; Guedeney, X.; Barre, J.; Benvenutti, C.; Navarro, N.; Vernillet, L.; Loisance, D.; Cachera, J.P.; Jacotot, B.; et al. Effects of plasma lipid levels on blood distribution and pharmacokinetics of cyclosporin A. Ther. Drug Monit. 1993, 15, 274-280. [CrossRef] [PubMed]

45. Wasan, K.M.; Pritchard, P.H.; Ramaswamy, M.; Wong, W.; Donnachie, E.M.; Brunner, L.J. Differences in lipoprotein lipid concentration and composition modify the plasma distribution of cyclosporine. Pharm. Res. 1997, 14, 1613-1620. [CrossRef] [PubMed]

46. Ben-Yashar, V.; Barenholz, Y. Characterization of the core and surface of human plasma lipoproteins. A study based on the use of five fluorophores. Chem. Phys. Lipids 1991, 60, 1-14. [CrossRef] 
47. Weinkam, R.J.; Finn, A.; Levin, V.A.; Kane, J.P. Lipophilic drugs and lipoproteins: Partitioning effects on chloroethylnitrosourea reaction rates in serum. J. Pharmacol. Exp. Ther. 1980, 214, 318-323.

48. Shen, B.W.; Scanu, A.M.; Kezdy, F.J. Structure of human serum lipoproteins inferred from compositional analysis. Proc. Natl. Acad. Sci. USA 1977, 74, 837-841. [CrossRef]

49. Simons, K.; Vaz, W.L. Model systems, lipid rafts, and cell membranes. Annu. Rev. Biophys. Biomol. Struct. 2004, 33, 269-295. [CrossRef]

50. Wasan, K.M.; Cassidy, S.M. Role of plasma lipoproteins in modifying the biological activity of hydrophobic drugs. J. Pharm. Sci. 1998, 87, 411-424. [CrossRef]

51. Krieger, M.; Brown, M.S.; Faust, J.R.; Goldstein, J.L. Replacement of endogenous cholesteryl esters of low density lipoprotein with exogenous cholesteryl linoleate. Reconstitution of a biologically active lipoprotein particle. J. Biol. Chem. 1978, 253, 4093-4101.

52. Kader, A.; Davis, P.J.; Kara, M.; Liu, H. Drug targeting using low density lipoprotein (LDL): Physicochemical factors affecting drug loading into LDL particles. J. Control. Release 1998, 55, 231-243. [CrossRef]

53. Mooberry, L.; Sabnis, N.; Lacko, A. Optimization of Reconstituted High Density Lipoprotein (rHDL) nanoparticles (NPs) for Short-Interfering RNA (siRNA) Delivery. FASEB J. 2017, 31, 611-614. [CrossRef]

54. Corbin, I.R. Ligand-Coupled Lipoprotein for Ovarian Cancer-Specific Drug Delivery. In Ovarian Cancer: Methods and Protocols; Malek, A., Tchernitsa, O., Eds.; Humana Press: Totowa, NJ, USA, 2013; pp. 467-480. [CrossRef]

55. Corbin, I.R.; Li, H.; Chen, J.; Lund-Katz, S.; Zhou, R.; Glickson, J.D.; Zheng, G. Low-density lipoprotein nanoparticles as magnetic resonance imaging contrast agents. Neoplasia 2006, 8, 488-498. [CrossRef] [PubMed]

56. Kitahara, C.M.; Berrington de Gonzalez, A.; Freedman, N.D.; Huxley, R.; Mok, Y.; Jee, S.H.; Samet, J.M. Total cholesterol and cancer risk in a large prospective study in Korea. J. Clin. Oncol. 2011, 29, 1592-1598. [CrossRef] [PubMed]

57. Strohmaier, S.; Edlinger, M.; Manjer, J.; Stocks, T.; Bjorge, T.; Borena, W.; Haggstrom, C.; Engeland, A.; Nagel, G.; Almquist, M.; et al. Total serum cholesterol and cancer incidence in the Metabolic syndrome and Cancer Project (Me-Can). PLoS ONE 2013, 8, e54242. [CrossRef] [PubMed]

58. Hiatt, R.A.; Fireman, B.H. Serum cholesterol and the incidence of cancer in a large cohort. J. Chronic. Dis. 1986, 39, 861-870. [CrossRef]

59. Strasak, A.M.; Pfeiffer, R.M.; Brant, L.J.; Rapp, K.; Hilbe, W.; Oberaigner, W.; Lang, S.; Borena, W.; Concin, H.; Diem, G.; et al. Time-dependent association of total serum cholesterol and cancer incidence in a cohort of 172,210 men and women: A prospective 19-year follow-up study. Ann. Oncol. 2009, 20, 1113-1120. [CrossRef]

60. McMichael, A.J.; Jensen, O.M.; Parkin, D.M.; Zaridze, D.G. Dietary and endogenous cholesterol and human cancer. Epidemiol. Rev. 1984, 6, 192-216. [CrossRef]

61. Miller, S.R.; Tartter, P.I.; Papatestas, A.E.; Slater, G.; Aufses, A.H., Jr. Serum cholesterol and human colon cancer. J. Natl. Cancer Inst. 1981, 67, 297-300. [CrossRef]

62. Vitols, S.; Bjorkholm, M.; Gahrton, G.; Peterson, C. Hypocholesterolemia in Malignancy Due to Elevated Low-Density-Lipoprotein-Receptor Activity in Tumor-Cells-Evidence from Studies in Patients with Leukemia. Lancet 1985, 2, 1150-1154. [CrossRef]

63. Peterson, C.; Vitols, S.; Rudling, M.; Blomgren, H.; Edsmyr, F.; Skoog, L. Hypocholesterolemia in Cancer-Patients May Be Caused by Elevated Ldl Receptor Activities in Malignant-Cells. Med. Oncol. Tumor. Phar. 1985, 2, 143-147. [CrossRef]

64. Budd, D.; Ginsberg, H. Hypocholesterolemia and Acute Myelogenous Leukemia - Association between Disease-Activity and Plasma Low-Density-Lipoprotein Cholesterol Concentrations. Cancer 1986, 58, 1361-1365. [CrossRef]

65. Neugut, A.I.; Johnsen, C.M.; Fink, D.J. Serum Cholesterol Levels in Adenomatous Polyps and Cancer of the Colon: A Case-Control Study. JAMA 1986, 255, 365-367. [CrossRef] [PubMed]

66. Bani, I.A.; Williams, C.M.; Boulter, P.S.; Dickerson, J.W. Plasma lipids and prolactin in patients with breast cancer. Br. J. Cancer 1986, 54, 439-446. [CrossRef] [PubMed]

67. Reverter, J.C.; Sierra, J.; Marti-Tutusaus, J.M.; Montserrat, E.; Granena, A.; Rozman, C. Hypocholesterolemia in acute myelogenous leukemia. Eur. J. Haematol. 1988, 41, 317-320. [CrossRef] [PubMed] 
68. Marini, A.; Carulli, G.; Azzarà, A.; Grassi, B.; Ambrogi, F. Serum Cholesterol and Triglycerides in Hematological Malignancies. Acta Haematol. 1989, 81, 75-79. [CrossRef]

69. Rudling, M.J.; Angelin, B.; Peterson, C.O.; Collins, V.P. Low Density Lipoprotein Receptor Activity in Human Intracranial Tumors and Its Relation to the Cholesterol Requirement. Cancer Res. 1990, 50, 483.

70. Dessi, S.; Batetta, B.; Pulisci, D.; Accogli, P.; Pani, P.; Broccia, G. Total and HDL cholesterol in human hematologic neoplasms. Int. J. Hematol. 1991, 54, 483-486.

71. Shokumbi, W.A.; Ahaneku, J.E.; Okpala, I.E. Cholesterol, lipoprotein and phospholipid levels in acute lymphoblastic leukaemia. Eur. J. Haematol. 1991, 46, 59-61. [CrossRef]

72. Kritchevsky, S.B.; Wilcosky, T.C.; Morris, D.L.; Truong, K.N.; Tyroler, H.A. Changes in plasma lipid and lipoprotein cholesterol and weight prior to the diagnosis of cancer. Cancer Res. 1991, 51, 3198-3203.

73. Alexopoulos, C.G.; Pournaras, S.; Vaslamatzis, M.; Avgerinos, A.; Raptis, S. Changes in serum lipids and lipoproteins in cancer patients during chemotherapy. Cancer Chemother. Pharmacol. 1992, 30, 412-416. [CrossRef] [PubMed]

74. Dessi, S.; Batetta, B.; Pulisci, D.; Spano, O.; Cherchi, R.; Lanfranco, G.; Tessitore, L.; Costelli, P.; Baccino, F.M.; Anchisi, C.; et al. Altered pattern of lipid metabolism in patients with lung cancer. Oncology 1992, 49, 436-441. [CrossRef] [PubMed]

75. Umeki, S. Decreases in serum cholesterol levels in advanced lung cancer. Respiration 1993, 60, $178-181$. [CrossRef] [PubMed]

76. Bayerdorffer, E.; Mannes, G.A.; Richter, W.O.; Ochsenkuhn, T.; Seeholzer, G.; Kopcke, W.; Wiebecke, B.; Paumgartner, G. Decreased High-Density Lipoprotein Cholesterol and Increased Low-Density Cholesterol Levels in Patients with Colorectal Adenomas. Ann.Intern. Med. 1993, 118, 481-487. [CrossRef]

77. Potischman, N.; Hoover, R.N.; Brinton, L.A.; Swanson, C.A.; Herrero, R.; Tenorio, F.; de Britton, R.C.; Gaitan, E.; Reeves, W.C. The relations between cervical cancer and serological markers of nutritional status. Nutr. Cancer 1994, 21, 193-201. [CrossRef]

78. Baroni, S.; Scribano, D.; Pagano, L.; Zuppi, C.; Leone, G.; Giardina, B. Lipids and lipoproteins in acute lymphoblastic leukaemia (ALL). Leukemia Res. 1994, 18, 643-644. [CrossRef]

79. Kokoglu, E.; Karaarslan, I.; Karaarslan, H.M.; Baloglu, H. Alterations of serum lipids and lipoproteins in breast cancer. Cancer Lett. 1994, 82, 175-178. [CrossRef]

80. Juliusson, G.; Vitols, S.; Liliemark, J. Disease-Related Hypocholesterolemia in Patients with Hairy-Cell Leukemia - Positive Correlation with Spleen Size but Not with Tumor-Cell Burden or Low-Density-Lipoprotein Receptor Activity. Cancer 1995, 76, 423-428. [CrossRef]

81. Niendorf, A.; Nagele, H.; Gerding, D.; Meyer-Pannwitt, U.; Gebhardt, A. Increased LDL receptor mRNA expression in colon cancer is correlated with a rise in plasma cholesterol levels after curative surgery. Int. J. Cancer 1995, 61, 461-464. [CrossRef]

82. Dessi, S.; Batetta, B.; Spano, O.; Sanna, F.; Tonello, M.; Giacchino, M.; Tessitore, L.; Costelli, P.; Baccino, F.M.; Madon, E.; et al. Clinical remission is associated with restoration of normal high-density lipoprotein cholesterol levels in children with malignancies. Clin. Sci. 1995, 89, 505-510. [CrossRef]

83. AvallLundqvist, E.H.; Peterson, C.O. Serum cholesterol and apolipoprotein B levels may reflect disease activity in ovarian cancer patients. Acta Oncol. 1996, 35, 1007-1010. [CrossRef] [PubMed]

84. Grieb, P.; Ryba, M.S.; Jagielski, J.; Gackowski, W.; Paczkowski, P.; Chrapusta, S.J. Serum cholesterol in cerebral malignancies. J. Neuro-Oncol. 1999, 41, 175-180. [CrossRef] [PubMed]

85. Siemianowicz, K.; Gminski, J.; Stajszczyk, M.; Wojakowski, W.; Goss, M.; Machalski, M.; Telega, A.; Brulinski, K.; Magiera-Molendowska, H. Serum HDL cholesterol concentration in patients with squamous cell and small cell lung cancer. Int. J. Mol. Med. 2000, 6, 307-311. [CrossRef] [PubMed]

86. Siemianowicz, K.; Gminski, J.; Stajszczyk, M.; Wojakowski, W.; Goss, M.; Machalski, M.; Telega, A.; Brulinski, K.; Magiera-Molendowska, H. Serum total cholesterol and triglycerides levels in patients with lung cancer. Int. J. Mol. Med. 2000, 5, 201-205. [CrossRef] [PubMed]

87. Fiorenza, A.M.; Branchi, A.; Sommariva, D. Serum lipoprotein profile in patients with cancer. A comparison with non-cancer subjects. Int. J. Clin. Lab. Res. 2000, 30, 141-145. [CrossRef]

88. Abiaka, C.; Al-Awadi, F.; Al-Sayer, H.; Gulshan, S.; Behbehani, A.; Farghally, M.; Simbeye, A. Serum antioxidant and cholesterol levels in patients with different types of cancer. J. Clin. Lab. Anal. 2001, 15, 324-330. [CrossRef] 
89. Caruso, M.G.; Notarnicola, M.; Cavallini, A.; Di Leo, A. Low density lipoprotein receptor and mRNA expression in human colorectal cancer. Anticancer Res. 2001, 21, 429-433.

90. Tomiki, Y.; Suda, S.; Tanaka, M.; Okuzawa, A.; Matsuda, M.; Ishibiki, Y.; Sakamoto, K.; Kamano, T.; Tsurumaru, M.; Watanabe, Y. Reduced low-density-lipoprotein cholesterol causing low serum cholesterol levels in gastrointestinal cancer: A case control study. J. Exp. Clin. Cancer Res. 2004, 23, 233-240.

91. Michalaki, V.; Koutroulis, G.; Syrigos, K.; Piperi, C.; Kalofoutis, A. Evaluation of serum lipids and high-density lipoprotein subfractions (HDL2, HDL3) in postmenopausal patients with breast cancer. Mol. Cell Biochem. 2005, 268, 19-24. [CrossRef]

92. Muntoni, S.; Atzori, L.; Mereu, R.; Satta, G.; Macis, M.D.; Congia, M.; Tedde, A.; Desogus, A.; Muntoni, S. Serum lipoproteins and cancer. Nutr. Metab. Cardiovasc. Dis. 2009, 19, 218-225. [CrossRef]

93. Li, X.; Liu, Z.L.; Wu, Y.T.; Wu, H.; Dai, W.; Arshad, B.; Xu, Z.; Li, H.; Wu, K.N.; Kong, L.Q. Status of lipid and lipoprotein in female breast cancer patients at initial diagnosis and during chemotherapy. Lipids Health Dis. 2018, 17, 6. [CrossRef] [PubMed]

94. Carr, B.I.; Giannelli, G.; Guerra, V.; Giannini, E.G.; Farinati, F.; Rapaccini, G.L.; Marco, M.D.; Zoli, M.; Caturelli, E.; Masotto, A.; et al. Plasma cholesterol and lipoprotein levels in relation to tumor aggressiveness and survival in HCC patients. Int. J. Biol. Markers 2018, 33, 423-431. [CrossRef] [PubMed]

95. Zhang, J.; Li, Q.; Wu, Y.; Wang, D.; Xu, L.; Zhang, Y.; Wang, S.; Wang, T.; Liu, F.; Zaky, M.Y.; et al. Cholesterol content in cell membrane maintains surface levels of ErbB2 and confers a therapeutic vulnerability in ErbB2-positive breast cancer. Cell Commun. Signal. 2019, 17, 15. [CrossRef]

96. Guo, S.; Wang, Y.; Zhou, D.; Li, Z. Significantly increased monounsaturated lipids relative to polyunsaturated lipids in six types of cancer microenvironment are observed by mass spectrometry imaging. Sci. Rep. 2014, 4, 5959. [CrossRef] [PubMed]

97. Li, Y.C.; Park, M.J.; Ye, S.-K.; Kim, C.-W.; Kim, Y.-N. Elevated Levels of Cholesterol-Rich Lipid Rafts in Cancer Cells Are Correlated with Apoptosis Sensitivity Induced by Cholesterol-Depleting Agents. Am. J. Pathol. 2006, 168, 1107-1118. [CrossRef]

98. Lettiero, B.; Inasu, M.; Kimbung, S.; Borgquist, S. Insensitivity to atorvastatin is associated with increased accumulation of intracellular lipid droplets and fatty acid metabolism in breast cancer cells. Sci. Rep. 2018, 8, 5462. [CrossRef]

99. Wang, T.; Seah, S.; Loh, X.; Chan, C.W.; Hartman, M.; Goh, B.C.; Lee, S.C. Simvastatin-induced breast cancer cell death and deactivation of PI3K/Akt and MAPK/ERK signalling are reversed by metabolic products of the mevalonate pathway. Oncotarget 2016, 7, 2532-2544. [CrossRef]

100. Wu, F.; Zhang, Y.; Sun, B.; McMahon, A.P.; Wang, Y. Hedgehog Signaling: From Basic Biology to Cancer Therapy. Cell Chem. Biol. 2017, 24, 252-280. [CrossRef]

101. Huang, P.; Nedelcu, D.; Watanabe, M.; Jao, C.; Kim, Y.; Liu, J.; Salic, A. Cellular Cholesterol Directly Activates Smoothened in Hedgehog Signaling. Cell 2016, 166, 1176-1187. [CrossRef]

102. Guixa-Gonzalez, R.; Albasanz, J.L.; Rodriguez-Espigares, I.; Pastor, M.; Sanz, F.; Marti-Solano, M.; Manna, M.; Martinez-Seara, H.; Hildebrand, P.W.; Martin, M.; et al. Membrane cholesterol access into a G-protein-coupled receptor. Nat. Commun. 2017, 8, 14505. [CrossRef]

103. Moon, H.; Ruelcke, J.E.; Choi, E.; Sharpe, L.J.; Nassar, Z.D.; Bielefeldt-Ohmann, H.; Parat, M.O.; Shah, A.; Francois, M.; Inder, K.L.; et al. Diet-induced hypercholesterolemia promotes androgen-independent prostate cancer metastasis via IQGAP1 and caveolin-1. Oncotarget 2015, 6, 7438-7453. [CrossRef] [PubMed]

104. Casaburi, I.; Chimento, A.; De Luca, A.; Nocito, M.; Sculco, S.; Avena, P.; Trotta, F.; Rago, V.; Sirianni, R.; Pezzi, V. Cholesterol as an Endogenous ERR $\alpha$ Agonist: A New Perspective to Cancer Treatment. Front. Endocrinol. 2018, 9. [CrossRef] [PubMed]

105. Nelson, E.R.; Wardell, S.E.; Jasper, J.S.; Park, S.; Suchindran, S.; Howe, M.K.; Carver, N.J.; Pillai, R.V.; Sullivan, P.M.; Sondhi, V.; et al. 27-Hydroxycholesterol Links Hypercholesterolemia and Breast Cancer Pathophysiology. Science 2013, 342, 1094. [CrossRef] [PubMed]

106. Amjad, F. Structural and Functional Diversity of Estrogen Receptor Ligands. Curr. Top. Med. Chem. 2015, 15, 1372-1384. [CrossRef]

107. Simigdala, N.; Gao, Q.; Pancholi, S.; Roberg-Larsen, H.; Zvelebil, M.; Ribas, R.; Folkerd, E.; Thompson, A.; Bhamra, A.; Dowsett, M.; et al. Cholesterol biosynthesis pathway as a novel mechanism of resistance to estrogen deprivation in estrogen receptor-positive breast cancer. Breast Cancer Res. 2016, 18, 58. [CrossRef] 
108. Wei, W.; Schwaid, A.G.; Wang, X.; Wang, X.; Chen, S.; Chu, Q.; Saghatelian, A.; Wan, Y. Ligand Activation of ERRalpha by Cholesterol Mediates Statin and Bisphosphonate Effects. Cell Metab. 2016, 23, 479-491. [CrossRef]

109. Divekar, S.D.; Tiek, D.M.; Fernandez, A.; Riggins, R.B. Estrogen-related receptor beta (ERRbeta)-renaissance receptor or receptor renaissance? Nucl. Recept. Signal. 2016, 14, e002. [CrossRef]

110. Wang, L.; Zuercher, W.J.; Consler, T.G.; Lambert, M.H.; Miller, A.B.; Orband-Miller, L.A.; McKee, D.D.; Willson, T.M.; Nolte, R.T. X-ray crystal structures of the estrogen-related receptor-gamma ligand binding domain in three functional states reveal the molecular basis of small molecule regulation. J. Biol. Chem. 2006, 281, 37773-37781. [CrossRef]

111. Simons, K.; Toomre, D. Lipid rafts and signal transduction. Nat. Rev. Mol. Cell Biol. 2000, 1, 31-39. [CrossRef]

112. Pike, L.J. The challenge of lipid rafts. J. Lipid Res. 2009, 50, S323-S328. [CrossRef]

113. Mollinedo, F.; Gajate, C. Lipid rafts as major platforms for signaling regulation in cancer. Adv. Biol. Regul. 2015, 57, 130-146. [CrossRef] [PubMed]

114. Irwin, M.E.; Mueller, K.L.; Bohin, N.; Ge, Y.; Boerner, J.L. Lipid raft localization of EGFR alters the response of cancer cells to the EGFR tyrosine kinase inhibitor gefitinib. J. Cell Physiol. 2011, 226, 2316-2328. [CrossRef] [PubMed]

115. Remacle-Bonnet, M.; Garrouste, F.; Baillat, G.; Andre, F.; Marvaldi, J.; Pommier, G. Membrane rafts segregate pro- from anti-apoptotic insulin-like growth factor-I receptor signaling in colon carcinoma cells stimulated by members of the tumor necrosis factor superfamily. Am. J. Pathol. 2005, 167, 761-773. [CrossRef]

116. Tseng, T.-H.; Hsu, J.-D.; Chu, C.-Y.; Wang, C.-J. Promotion of colon carcinogenesis through increasing lipid peroxidation induced in rats by a high cholesterol diet. Cancer Lett. 1996, 100, 81-87. [CrossRef]

117. Porter, N.A. A perspective on free radical autoxidation: The physical organic chemistry of polyunsaturated fatty acid and sterol peroxidation. J. Org. Chem. 2013, 78, 3511-3524. [CrossRef]

118. Lu, J.; Mitra, S.; Wang, X.; Khaidakov, M.; Mehta, J.L. Oxidative Stress and Lectin-Like Ox-LDL-Receptor LOX-1 in Atherogenesis and Tumorigenesis. Antioxid. Redox Signal. 2011, 15, 2301-2333. [CrossRef]

119. Khaidakov, M.; Mehta, J.L. Oxidized LDL triggers pro-oncogenic signaling in human breast mammary epithelial cells partly via stimulation of MiR-21. PLOS ONE 2012, 7, e46973. [CrossRef]

120. Eberlé, D.; Hegarty, B.; Bossard, P.; Ferré, P.; Foufelle, F. SREBP transcription factors: Master regulators of lipid homeostasis. Biochimie 2004, 86, 839-848. [CrossRef]

121. Yokoyama, C.; Wang, X.; Briggs, M.R.; Admon, A.; Wu, J.; Hua, X.; Goldstein, J.L.; Brown, M.S. SREBP-1, a basic-helix-loop-helix-leucine zipper protein that controls transcription of the low density lipoprotein receptor gene. Cell 1993, 75, 187-197. [CrossRef]

122. Porstmann, T.; Santos, C.R.; Griffiths, B.; Cully, M.; Wu, M.; Leevers, S.; Griffiths, J.R.; Chung, Y.-L.; Schulze, A. SREBP Activity Is Regulated by mTORC1 and Contributes to Akt-Dependent Cell Growth. Cell Metab. 2008, 8, 224-236. [CrossRef]

123. Hua, H.; Kong, Q.; Zhang, H.; Wang, J.; Luo, T.; Jiang, Y. Targeting mTOR for cancer therapy. J. Hematol. Oncol. 2019, 12, 71. [CrossRef] [PubMed]

124. Yue, S.; Li, J.; Lee, S.-Y.; Lee, H.J.; Shao, T.; Song, B.; Cheng, L.; Masterson, T.A.; Liu, X.; Ratliff, T.L.; et al. Cholesteryl Ester Accumulation Induced by PTEN Loss and PI3K/AKT Activation Underlies Human Prostate Cancer Aggressiveness. Cell Metab. 2014, 19, 393-406. [CrossRef] [PubMed]

125. Haskins, J.W.; Zhang, S.; Means, R.E.; Kelleher, J.K.; Cline, G.W.; Canfran-Duque, A.; Suarez, Y.; Stern, D.F. Neuregulin-activated ERBB4 induces the SREBP-2 cholesterol biosynthetic pathway and increases low-density lipoprotein uptake. Sci. Signal. 2015, 8, ra111. [CrossRef] [PubMed]

126. Liao, Y.; Hung, M.-C. Physiological regulation of Akt activity and stability. Am. J. Transl. Res. 2010, 2, 19-42. [PubMed]

127. George, K.S.; Wu, S. Lipid raft: A floating island of death or survival. Toxicol. Appl. Pharmacol. 2012, 259, 311-319. [CrossRef] [PubMed]

128. He, M.; Zhang, W.; Dong, Y.; Wang, L.; Fang, T.; Tang, W.; Lv, B.; Chen, G.; Yang, B.; Huang, P.; et al. Pro-inflammation NF- $\mathrm{KB}$ signaling triggers a positive feedback via enhancing cholesterol accumulation in liver cancer cells. J. Exp. Clin. Cancer Res. 2017, 36, 15. [CrossRef] [PubMed] 
129. Guo, D.; Reinitz, F.; Youssef, M.; Hong, C.; Nathanson, D.; Akhavan, D.; Kuga, D.; Amzajerdi, A.N.; Soto, H.; Zhu, S.; et al. An LXR Agonist Promotes Glioblastoma Cell Death through Inhibition of an EGFR/AKT/SREBP-1/LDLR-Dependent Pathway. Cancer Discov. 2011, 1, 442-456. [CrossRef]

130. Villa, G.R.; Hulce, J.J.; Zanca, C.; Bi, J.; Ikegami, S.; Cahill, G.L.; Gu, Y.; Lum, K.M.; Masui, K.; Yang, H.; et al. An LXR-Cholesterol Axis Creates a Metabolic Co-Dependency for Brain Cancers. Cancer Cell 2016, 30, 683-693. [CrossRef]

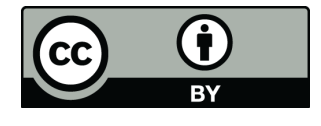

(C) 2019 by the authors. Licensee MDPI, Basel, Switzerland. This article is an open access article distributed under the terms and conditions of the Creative Commons Attribution (CC BY) license (http://creativecommons.org/licenses/by/4.0/). 